\title{
Institutions and Economic Growth in Sub-Saharan African Countries: The Effect of Investment Climate Quality
}

\author{
Nyemb Pagbe Rémi Degourmond, PhD
}

Centre for Studies and Research in Economics and Management (CEREG), University of Yaoundé II

\begin{abstract}
This paper assesses the impact of investment climate quality on economic growth for a sample of 21 countries in Sub-Saharan Africa (SSA), over the period 1996-2014. The investment climate is measured simultaneously by individual components and composite indices, in order to capture both its global and specific effects, with a view to possibly identifying the most determining factors in the economic growth of SSA countries. In addition, in order to verify the robustness of our results, two composite indices of investment climate were constructed using the Principal Component Analysis method, with variables from two main databases (the World Governance Indicators database of World Bank and the International Country Risk Guide database).

By using fixed and random effects models based on Hausman test results, we generally find that investment climate is a major determinant of economic growth in the countries of the SSA of the study sample. This result is valid regardless of the composite index or the individual component considered. Fight against corruption, protection of private property rights, efficiency of government, the quality of bureaucracy and regulation appear to be the most decisive components in accelerating economic growth for the sample of country considered.
\end{abstract}

Keywords: Institutions; investment climate; economic growth; panel data.

\section{Introduction}

Since the early 1990s, the development issue has displayed an institutional orientation which is reflected in a certain number of works (North, 1990; La Porta et al., 1997, 1999; Acemoglu and Robinson, 2000, 2005; Acemoglu et al., 2014), by the argument that the failure of development policies in most Third World countries is the result of the poor consideration of the quality of institutions. For many of these economists, the factors generally presented in the literature as being the determinants of economic growth such as innovation, capital accumulation, education, etc., are only manifestations thereof. Thus, the differentials in the levels and quality of economic growth between countries can be explained for the most part by differences in the quality of institutional arrangements.

In this wake, the United Nations Conference on Trade and Development (UNCTAD, 2012), stresses that investment is one of the engines of structural transformation. Moreover, according to certain studies (UNCTAD-ECA, 1999; Clarke, 2013), medium and long-term economic growth rates estimated at 7\% on average annually would be required for African countries to obtain appreciable results in terms of fight against poverty; which would require qualitative (oriented towards labor-intensive sectors) and quantitative investments estimated at $25 \%$ of GDP at least in these countries. However, not only have the investments mobilized in SSA in recent years not been very productive, but in addition, they have been below the levels required to sustainably reduce poverty and ensure the achievement of development objectives. By way of illustration, over the 1990-1999 period, an investment rate estimated at 18\% of GDP in SSA was recorded, compared with $24 \%$ of GDP for the other developing countries, while over the period 2000-2011, the figures are $19 \%$ of GDP against $26 \%$ of GDP. In this context, the major challenge for the countries of this region is to stimulate investments, the levels and quality of which are essential for economic transformation, hence many studies (Grindle, 2004; Rothstein and Uslaner, 2005; Hasan and al., 2007, etc.) highlight the importance of the quality of investment climate. 
According to the World Bank (2005), investment climate (I.C) can be defined as "the economic, institutional and behavioral environment, present and anticipated, which affects the profitability and the risks associated with investments. Also, it covers a vast field ranging from the regulatory framework, to the performance of companies through the functioning of the factor market in a given country. This means that, beyond its importance for companies, the I.C is decisive for the productivity of public investments; thereby helping to avoid wasting resources and achieving the best possible results.

Studies to date on the impact of I.C on economic performance have produced various results that have fueled controversy over whether a country's investment climate really determines its economic performance. Also, an additional contribution in this area, which is based on relatively recent data, and which takes into account the criticisms made in previous work, would not be superfluous.

This article thus sets itself the objective of assessing the impact of I.C quality on economic growth, using a sample of 21 countries in sub-Saharan Africa over the period 1996-2014. We defend the hypothesis that a "good" I.C quality has a positive impact on economic growth. Unlike previous work in the field which, on the whole, exclusively analyzed the impact, on the one hand, of the individual components of the I.C on economic growth, and on the other hand, of its composite indices (obtained by simple aggregation of the individual components) on economic growth, this work makes an additional contribution through:

- The alternating evaluation of the impact of individual and composite variables of I.C on economic growth. In order to verify the robustness of our results, two composite I.C indices are constructed from different institutional components of two main databases: the International Country Risk Guide (ICRG) of the Political Risk Services Group and the World Governance Indicators database of Kaufmann, Kraay and Mastruzzi (KKM) of the World Bank. This approach aims to reconcile the positions that oppose the advocates of taking into account, the institutional variables individually in the context of the evaluation of the impact of I.C on economic performance and those of the construction of a composite index of the I.C;

- The use of a Principal Component Analysis (PCA) for the construction of the I.C. composite index. This index only includes the institutional components which have a significant contribution to the construction of the main axis. Also, specific weights are automatically generated for each main variable according to its contribution. This approach thus makes it possible to correct the limit noted in certain previous works which, for the formation of the composite index, proceed by simple summation either of all the institutional variables listed in the database, or of some of them according to their degree of correlation, thus assigning a unique weighting to them, which however obscures the fact that these different variables affect economic performance ${ }^{1}$ neither with the same magnitude nor through the same channels;

- The concomitant assessment of the direct and indirect effects (via private investment) of the impact of the I.C on economic growth. In order to take advantage of the double dimension of the data, the panel data estimation method is used, in this case, the fixed and random individual effects according to the results of the Hausman test.

Overall, the results show that the quality of investment climate, regardless of its size, is crucial for economic growth. In terms of individual components, the fight against corruption, the protection of private property rights, the efficiency of government, the quality of bureaucracy and regulation appear to be the most decisive components in the acceleration of economic growth for the sample of countries considered.

The rest of this paper is structured as follows: section 2 (main text) discusses the literature review, analyzes the structure of economic growth in SSA and describes the data and the empirical approach. The results are discussed in section 3 while section 6 draws conclusions.

\section{Body text}

\subsection{Literature review}

\footnotetext{
${ }^{1}$ According to them, the concept I.C is very globalizing and therefore does not allow to highlight, the specific institutional components on which the States must give priority of action.
} 
Two major groups of work can be distinguished in this area: those whose approach consisted in the construction of one or more aggregated indices of the quality of the investment climate, in order to subsequently measure the impact on economic growth of countries, and those that have measured the impact of different specific components of the investment climate, on economic growth.

\subsubsection{Works highlighting the impact of various aggregate indices of the investment climate on economic growth}

Valeriani et al. (2011) assess the impact of institutional quality on economic growth on a sample of 181 countries divided into two major groups (developed and developing countries) over the period 1950-2009 (60 years) through a regression model in homogeneous panel and a fixed effects model. In their approach, they transformed the observations of each country into ten-year averages. Institutional quality is measured by three institutional variables: civil liberties, captured by the Freedom House variable, quality of government, captured by the aggregation of several variables from the ICRG base (bureaucracy, corruption and stability) and legislative checks and balances, captured by the number of counterweight structures, taken from the World Bank's Political Institutions Database. Overall, the results obtained are in line with the hypothesis that institutional quality has a positive and significant impact on economic growth, and these results are valid for both the sample of developed and developing countries.

In an important contribution, Rodrik et al. (2004) estimate the explanatory power of competing exogenous variables (institutions, economic policies, geography) using 4 regressions. They show that institutions (measured by a variable defining the power of the rule of law) dominate both economic policy (measured by openness to international trade) and geography, in explaining the differences in levels of per capita income between countries. More concretely, the authors revisit the question of whether legal and political institutional factors such as the rule of law count more than economic policies and geography in the economic success of countries. In this perspective, they use a variable created within the framework of the World Bank Doing Business project, which measures the business environment in general. The main results show that the Doing Business indicator appears as the key explanatory variable for per capita income, in a set of regressions of instrumental variables. More importantly, the inclusion of the Doing Business indicator concomitantly with other institutional and legal variables leads to obtaining significant results for all, while the mere taking into account of these does not produce significant results. Hall and Jones (1999) examined the impact of what they called "social infrastructure" (a combination of political institutional variables, openness to international trade, etc. weighted equally) on the level of development of a set of countries. From instruments such as distance from the equator, they found a positive impact of social infrastructure on per capita income levels. Kaufmann et al. (1999b) studied the correlation between six (06) aggregate indicators of governance and economic performance measured by per capita income, infant mortality and the literacy rate. They found that each indicator was positively correlated with the logarithm of GDP / capita and the literacy rate, and negatively with the infant mortality rate. Taking as reference the approach formalized by Hall and Jones (1999), they use several governance indicators collected from several sources, to define the nature of the relationship that can exist between governance and economic growth over a large sample of country. They regressed between the three dependent variables (logarithm of GDP / capita, infant mortality rate, and literacy rate) and the six (06) governance indicators. The main conclusion they reach is that "good governance" is crucial for economic performance. Estimates have shown that an increase in the standard deviation for one of the governance indicators leads to growth of $25 \%$ (for the variable Voice and Accountability) to 4 times more (for Political Instabiliy and Absence of Violence) per capita income; to a $2.5 \%$ to 4 times more decrease in the infant mortality rate and to a $15 \%$ to 25 times more increase in the literacy rate.

Knack and Keefer (1999) use two indicators collected by private organizations (International Country Risk Guide - ICRG - and Business Environment Risk Intelligence - BERI) to measure the security of property rights, the reports of which provide a set of security indicators of contract and property rights. They find that the ICRG indicators in particular are closely linked to national performance in growth regressions.

Brunetti et al. (1997) show that the "credibility" index (constructed as an average of predictability in the formalization of rules, the subjective perception of political stability, the security of persons and property, 
the predictability of the judicial system, and the corruption) positively influences both private investment and economic growth. On the basis of this credibility indicator constructed on the basis of data obtained following a survey carried out in the private sector in 73 countries and covering 3800 companies, the authors tested its effects and those of its different components, on investment and economic growth through standard regressions. They find that low credibility of the rules translates into low investment rates and economic growth.

Knack and Keefer (1995) assess the impact of institutions on economic performance (economic growth and private investment). The institutions to which they refer in their article are the security of property rights and the enforceability of the contracts which they capture from composite indices constructed on the basis of variables from two different databases, ICRG and BERI. For the ICRG database, they use five variables to build the security index of property rights and contracts: (i) the risk of expropriation, (ii) the rule of law, (iii) the risk of government termination of contracts, (iv) corruption in government and, (v) quality of bureaucracy. For the BERI database, the authors use four variables: (i) the enforceability of contracts, (ii) the quality of the infrastructure, (iii) the potential for nationalization and, (iv) regulatory deadlines. From these components, they construct six composite indices by simple summation of the components of each database. In essence, their study, which neglects the issue of investment endogeneity, shows that the institutions that provide security of property and contract rights are crucial for investment and economic growth. The effects of institutions on economic growth remain significant even after the introduction of investment in the model, thus suggesting that security of property and contract rights affects not only the volume of investment, but also the efficiency with which the factors of production are allocated.

The criticism generally addressed to this category of work is that it aggregates different aspects of I.C which do not necessarily have a similar impact on economic performance. In fact, this does not make it possible to define priorities for improving specific aspects of I.C. Therefore, empirical work has examined the relationships between certain components of I.C and economic growth.

\subsubsection{Works highlighting the impact of specific components of investment climate on economic growth}

The components of the I.C generally used in this context, refer to the state of infrastructure, access to finance, security (crime and corruption), the rule of law, property and contract rights, the framework regulatory and institutional of a country, etc. The majority of studies here, highlights significant links between these components and economic performance of countries. The results suggest that an improvement in the quality of I.C has a favorable impact on economic growth of countries. Zouhaier H. (2012) assesses the effects of institutional factors on investment and economic growth for a sample of 11 countries in the Middle East and North Africa (MENA) region, over the period 2000-2009. Institutional factors are captured here by three main variables: civil liberties, political instability and corruption. From a dynamic panel, the effects of institutions on the contribution of investment to economic growth are assessed. The key results obtained from these empirical evaluations show: (i) a significant relationship between institutional variables and investment on the one hand, and on the other hand, between the former and economic growth, (ii) a positive interaction between political institutions and investment and, (iii) a negative interaction between political instability and investment.

Straub et al. (2008) establish a positive relationship between infrastructure and economic growth, especially in poor countries, but conclude that, in general, the results of studies lack robustness. Jerzmanowski (2006) favors economic institutions and find a positive and significant effect of these on the occurrence of favorable and lasting growth regime changes. Its analysis is based on data covering the period 1962-1994 for a sample of 82 developed countries and developing countries (PED).

Guetat (2006) separated the impact of corruption on growth in MENA countries from that of Asian and SSA countries by estimating a model of economic growth on a sample of 90 countries over the period 1960-2000. She introduced regional dummy variables and used terms of interaction between regression variables and regional dummies to distinguish regional specific effects. The results indicated that corruption deteriorated growth more significantly in MENA countries than in Latin America and other regions. 
Johnson et al. (2002), on a sample of former communist countries in Europe, show that the protection of private property rights is a necessary and sufficient condition for the development of private investment and economic growth in these countries.

Kaufmann and Kraay (2002) examine the relationship between per capita income and the quality of economic governance, more specifically, the protection of private property rights, using data from the 20002001 period covering 175 developed and in development countries. Through the results of these authors, it appears that the improvement in the quality of private property rights institutions is favorable to the increase in per capita income.

Mo (2000) assessed the impact of corruption on economic growth and the channels through which it affects growth, using data similar to that of Mauro (1995). He found that a $1 \%$ increase in the level of corruption reduces the growth rate by about $0.72 \%$ and the most important channel of this impact is political instability which accounts for about $53 \%$ of the total effect. He also found that corruption lowers the level of human capital and the share of private investment. Ehrlich and Lui (1999) researched the link between corruption, government and economic growth using panel data that included 68 countries over the period 1981-1992. They found that variations in both the size of government and the degree of corruption, in the opposite direction, influence per capita income, but not necessarily its long-term growth rate, in most developed countries.

Poirson Helene (1998) assesses the impact of specific components of the I.C (which she calls economic security) on investment and economic growth. It uses the panel data method on a sample of 53 developing countries over the period 1984-1995. The results obtained show that: (i) private investment is significantly influenced by the risk of expropriation, the degree of civil liberty and the quality of the bureaucracy; (ii) reducing the potential risks of expropriation and political terrorism are the most decisive security factors in accelerating economic growth; (iii) corruption and the risk of termination of contracts also have an impact on economic growth, but only in the long term.

La Porta et al. (1997b) and Knack and Keefer (1997a), examine the effects of "informal rules" (trust) on economic performance and find that this trust exerts a positive influence on economic growth, more important than formal institutional rules.

Alesina et al. (1996) analyze the effect of coups on economic growth, and conclude that it is negative for the countries and periods in which such unconstitutional changes of government have occurred.

Mauro (1995) identified the impact of corruption and other institutional factors, including the cost of bureaucracy, the efficiency of the justice system and variables of political stability, on economic growth using a database from 67 countries over the period 1980-1983. Through cross-sectional regressions, he finds that corruption hampers economic growth by reducing private investment.

Gyimah-Brempong (1995) uses a panel of thirty-eight African countries over the period 1975-1988 to assess the impact of political instability on economic growth. It takes into account not only the instability measured by changes or attempts to change leaders (coups, conspiracies), but also that which does not directly affect the elites (strikes, demonstrations, etc.). He also studies the interaction between political instability and economic progress in a system of equations explaining savings, investment, growth and political instability simultaneously. The results obtained are all in the right direction. However, the influence of economic policies implemented by the government in power is not taken into account so that the results obtained do not provide any economic policy recommendations.

Barro and Sala-I-Martin (1995) use the "institutional quality" index of Knack and Keefer (1995) to determine the contribution of its various components. In this case, they find that only rules and laws have a significant impact on economic growth after controlling for a variety of variables in the institutional environment, including a measure of political revolutions and assassinations.

Hadjimichael and Ghura (1995), using macroeconomic uncertainty components as control instruments, found across a sample of African countries a significant impact of civil liberties and political rights on private investment and economic growth. 
Fosu (1992) examines with cross-sectional data on 31 African countries the effect of political instability on growth, taking into account the growth of factors of production and that of exports. He finds that political instability has a negative and significant effect, suggesting that factor productivity is negatively affected by political instability. According to him, this result is due to the fact that it (political instability) reduces the quality of the factors of production by an effect of flight of human capital.

Barro (1991) assessed the impact of the institutional environment on the basis of the variable political violence captured by the coup d'etat and revolutions and, assassinations, components of economic growth. In this work, the author does not integrate the private investment variable to capture the indirect effect of institutional variables on economic growth or even to solve the endogeneity problem. The results show a negative impact of political violence on economic growth. It is important to note that even this second category of studies generally faces a number of criticisms. Indeed, critics are very often addressed to them on the one hand, to dwell only on a few aspects of the I.C and on the other hand, despite the fact that they consider the specific aspects of the I.C, disaggregate them to allow a better and more precise orientation of the recommendations for improvement of the I.C towards the public authorities.

This article thus integrates all of these criticisms by adopting the approach described above.

\subsection{Economic growth in SSA: need for restructuring}

The economic history of Africa since independence has been characterized by considerable fluctuations. There are two main periods of growth, accompanied by a period of stagnation in between, as illustrated in the figure below:

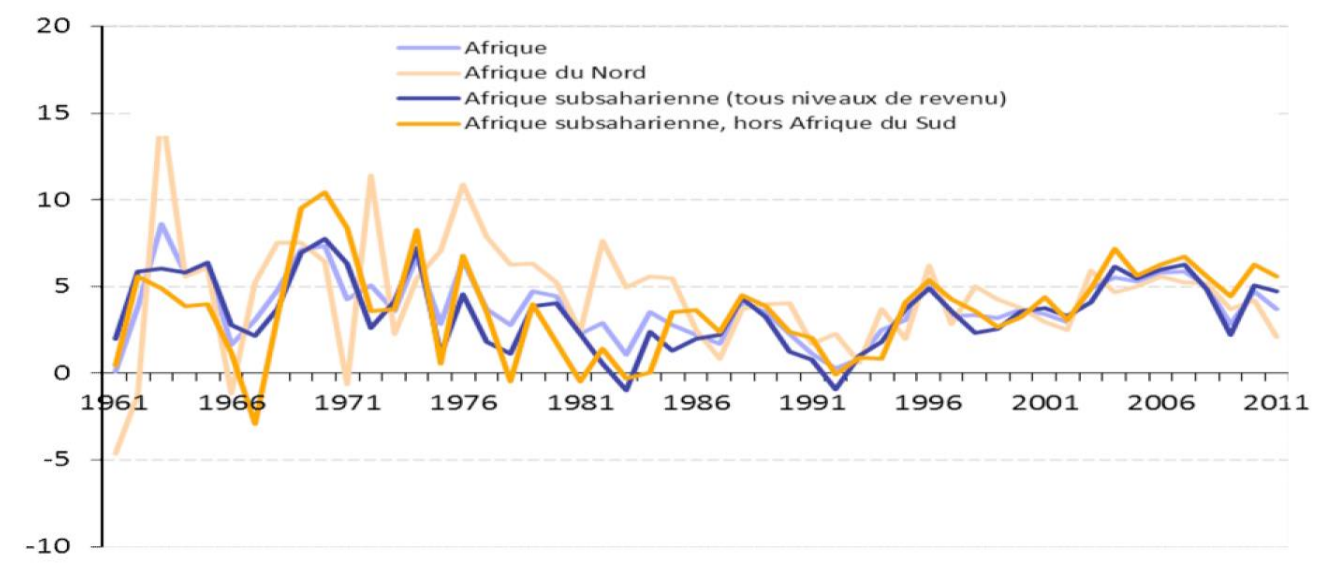

Figure 1: Percentage GDP growth (1961 to 2011)

\section{Source: World Bank, African Development Indicators, 2013}

The first period, from 1961 to 1975, was the one in which the continent recorded the most significant performances, owing in particular to a relatively stable world economic situation favorable to the structure of its economy. Indeed, during this period, there were, among other performances, sustained growth rates of more than $5 \%$ in many cases, to the point where these results led to favorable comparisons in terms of development prospects, with Southeast Asia, which at that time was not only entangled in conflicts, but above all marked by an ambient poverty which foreshadowed the economic failure of this region. However, this growth came to an abrupt end in 1979 concomitantly with the oil crisis.

The second period, from 1995 to 2011, was characterized at the start by a timid economic recovery, consecutive to the two decades of turbulence on the continent. The decline occurred at the turn of the year 2000 when, due to various measures taken by the public authorities in response to previous economic problems, Africa returned to phases of sustained growth, with in this case rates of $6.6 \%$ on annual average over the 2004-2008 period, 7\% and 5\% respectively in 2010 and 2011, recorded in SSA (Source: IMF, World Economic Outlook database, 2015).

However, during 2011, world prices for basic products (energy, metals, and to a lesser extent, food products) began to decline, which accelerated from mid-2014. Crude oil prices fell by the IMF by some $70 \%$ between 
June 2014 and February 2016, while the metal price index fell 35\% from 2011 to 2017. This downward trend in commodity prices is again translated on the whole, by a deterioration of the economic situation of the countries of the region. According to the IMF, in almost half of the 45 countries that make up the SSA, economic growth has deviated unfavorably from the path it followed before the external environment deteriorated. It slowed down significantly in 2015, where we recorded an economic growth rate of $3.4 \%$ against 5.1\% in 2014 and, moreover, the situation worsened in 2016, with an economic growth rate of $1.4 \%$, the lowest level in two decades.

Furthermore, even if it can be noted that economic growth in this region has remained positive and higher than that of other regions in the world, it is important to emphasize that the GDP per capita of many SSA countries remains far below that of other regions, as illustrated in the figure below:

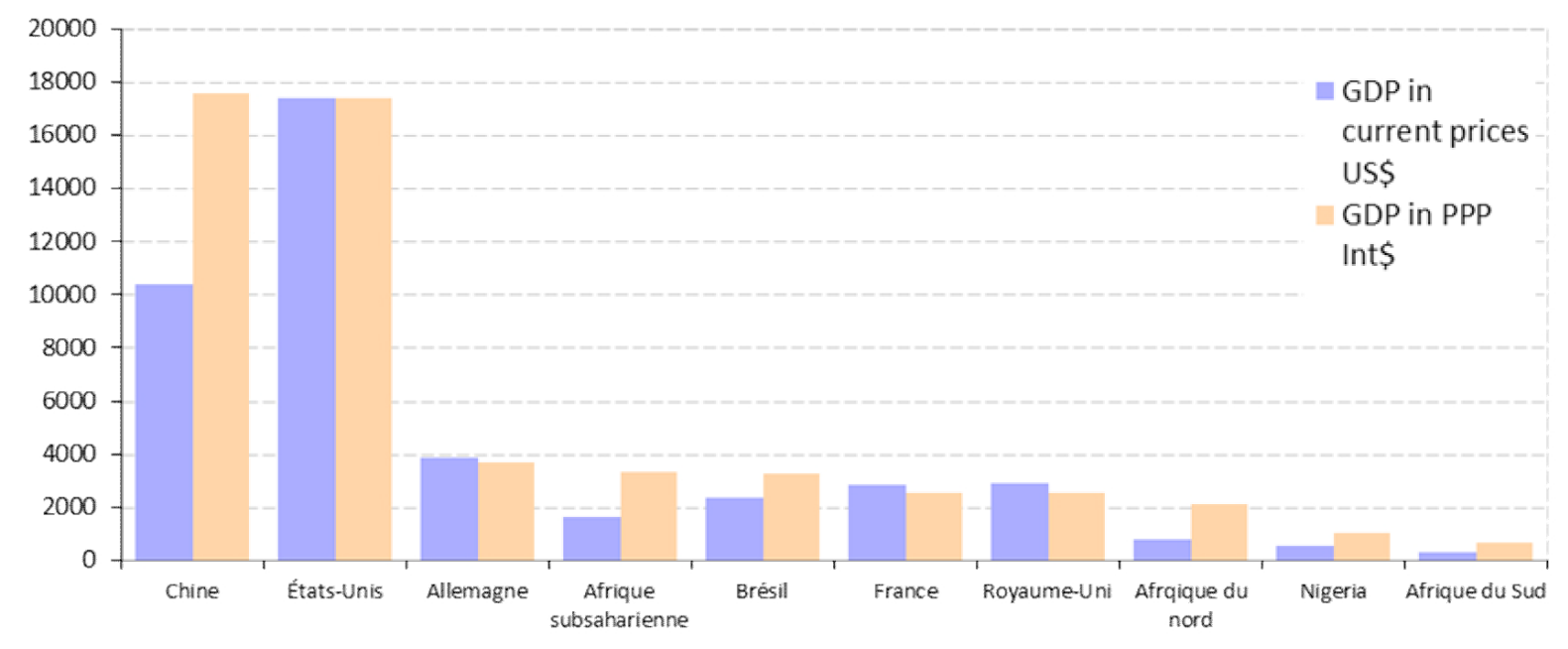

Figure 2: Comparative view of estimated PPP GDP in billion US dollars, 2014

\section{Source: IMF, World Economic Outlook, April 2015}

Most of the countries in this region have a GDP per capita in purchasing power parity, less than US $\$ 5,000$, and those which exceed this threshold are either exporters of oil or minerals, or more diversified economies (such as Cape Verde, Mauritius, South Africa, Seychelles, etc.). However, while SSA represents 18\% of the earth's surface, it produces only $1.5 \%$ of world GDP. The apparent link which emerges between the development of world prices of basic products and that of the economic growth rates recorded in SSA, as well as the weak share of the GDP of this region compared to world GDP, lead to question the precariousness of its economy. In its Africa's pulse report of October 2016, the World Bank analyzes sectoral growth over the periods 1995-2008 and 2014-2016 of SSA countries. It emerges in general that, many African countries are characterized by a dependence on the export of one or more raw materials of which oil, gold and natural gas represent according to the World Bank, more than 90 $\%$ of all exports from the eight main black gold exporting countries, and 30\% of their GDP; all things which, according to this institution, increase their vulnerability to external shocks, in this case those resulting from the fall in the prices of these products, all the more so as the coupling of the extraction sector with the rest of the economy is weak in those countries that have rarely managed to diversify their economies. In fact, the extractive industries in these countries have generated few jobs. This is the case in Nigeria for oil, in Ghana for gold, in Zambia for copper, in the DRC for cobalt, in Namibia and Niger for uranium, in Guinea for bauxite and until recently, in Botswana for diamonds. The situation is similar for agricultural exporters such as Kenya (the third largest tea exporter in the world after China and India) and Ethiopia, a major producer of coffee.

Contrary to what has happened in other developing regions such as Latin America and Asia, net exports of basic products have increased, for the region as a whole, by $2 \%$ of GDP in the years 80 , at $6 \%$ of GDP over the 2010-2014 period, mainly due to the expansion of exports of products from the extractive industries (petroleum and metals). In fact, even if the rise in the prices of products from the extractive industries partly supported the strong growth of previous decades, the region's vulnerability to volatility in commodity prices 
has also increased; an evolution which some of these countries are paying the price today. The oil exporting countries are by far the most exposed. The shock to the terms of trade in basic products, which reflects the loss of income resulting from price fluctuations in terms of GDP, has been particularly marked for them since the middle of 2014. The terms of trade index commodities fell on average by $20 \%$ of GDP in a few years, after having steadily increased by around $45 \%$ over the period 2000-2014. IMF analyzes suggest that a negative terms of trade shock of this magnitude generally translates into a slowdown in annual growth of 3 to 3.25 points for several years. This is indeed the order of magnitude observed in the oil-exporting SSA countries.

Overall, the region's metal exporting countries were relatively less affected. This is because they export a wider range of commodities and that they play a less important role in their economies.

Overall, the end of the raw materials "super cycle" highlighted the vulnerability of the economic structure of SSA countries. In view of the IMF and World bank forecasts which point to a favorable return to the situation which would be long-term, due in particular to a continuous decline and / or to keeping low levels in the short and medium term, of the prices of many raw materials, it is more than ever essential to promote a new boom for the countries of this region. Also, beyond the traditional economic policy measures which aim at reforming the production structure of these economies, and whose implementation or inclinations to implement for decades have not produced the expected effects, it would perhaps be advisable, on the fringes of the conduct of economic policies specific to each of the countries of this region, for them to resolutely engage in a dynamic of structural public reforms, conducive to the development of private initiatives. Indeed, the resilience shown by a certain number of African countries - more or less dependent on the export of basic products - in the face of the unfavorable economic conditions which has prevailed since 2011, and which has been generally attributed to the implementation in these, of numerous institutional reforms and, in a specific way, of the quality of the climate of the investment, leads to wonder about the role of the latter, in the restoration of the levels of growth favorable to the development from SSA countries.

The figure below makes it possible to lay the groundwork for this relationship:

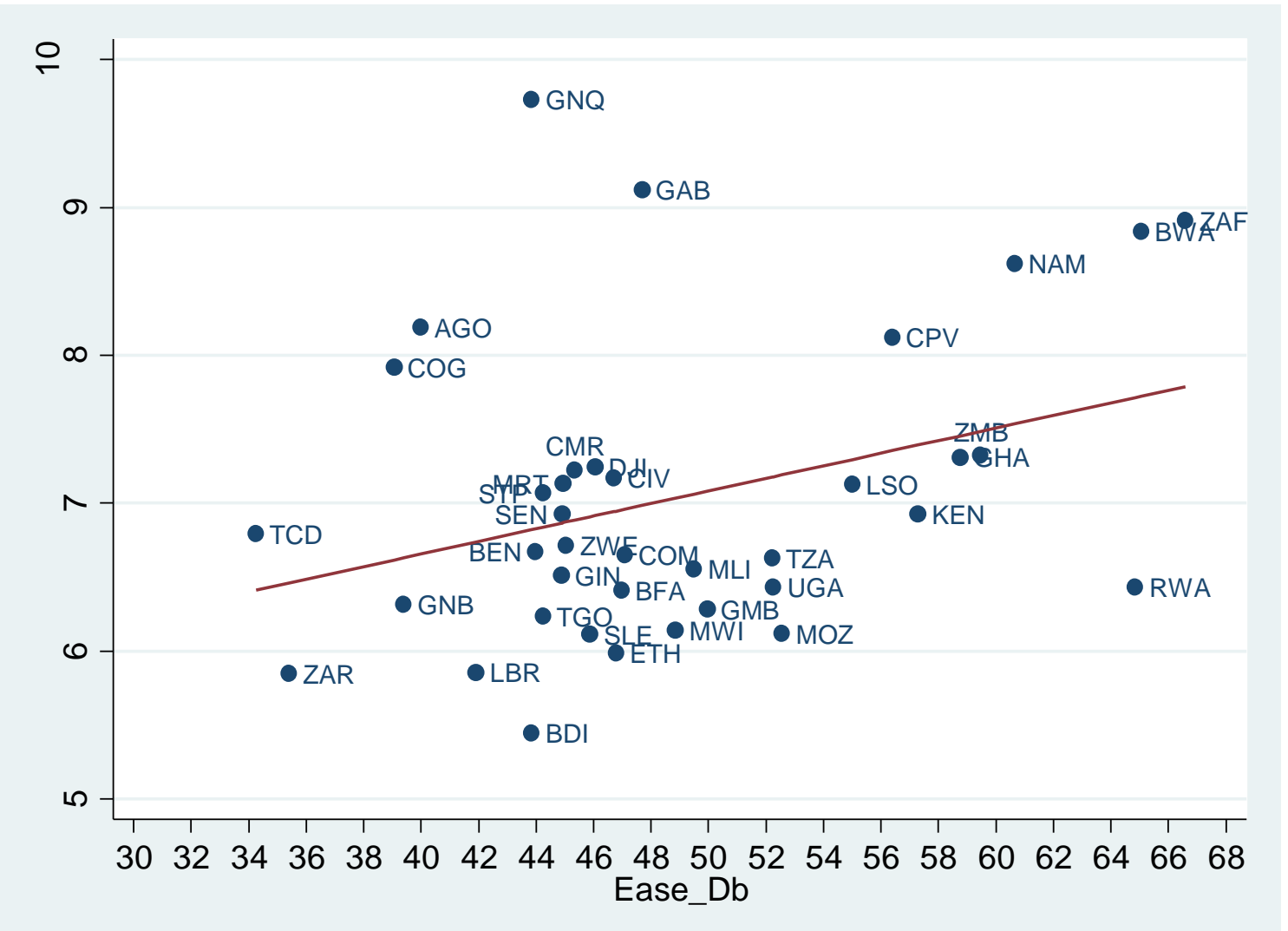

Figure 3: Scatter plot of the relationship between per capita GDP and Ease of doing business in Africa Source: the author from the World Bank's Doing Business and WDI databases 
Overall, it appears that the better the quality of I.C, the better the performance in terms of economic growth. This relationship will be subject to empirical evaluation in the following pages.

\subsection{Data and empirical approach}

\subsubsection{Description of the study data}

Variables of the investment climate: They come from two main databases: the Worldwide Governance Indicators (WGI) database and the International Country Risk Guide (ICRG) database. In addition, the variable protection of private property rights (RIGHTS_FI) is extracted from the Fraser Institute database to densify the economic dimension.

Regarding the WGI database, six (06) indicators are retained. Democracy (VOICE_ACCOUNT_KKM) which captures perceptions of the degree of participation of the citizens of a country in the choice of their government, in freedom of expression, association and the media. Political stability (POL_STABIL_ABS_VIOLENCE_KKM) which measures the likelihood that a government will be destabilized or overthrown by unconstitutional or violent means. The Effectiveness of Public Governance (GOV_EFFECTIV_KKM) which measures the quality of public services. The quality of administrative regulation (REGUL_QUAL_KKM) indicates the government's ability to formulate and implement major policies and regulations that promote the development of the private sector. The rule of law (RUL_LAW_KKM) measures the enforceability of contracts and the quality of property rights, the police and the courts. Corruption (CONTROL_CORRUPT_KKM) indicates the use of public power for private gain. The set of indicators ranges from -2.5 (poor investment climate) to 2.5 (good investment climate).

The indicators in the ICRG database were initially eleven (11); the twelfth being the variable protection of private property rights from the Fraser Institute database. Ten variables (10) were selected by the PCA method as being significant in the construction of the composite index, including nine (09) from the ICRG database. These same ten (10) variables are retained as individual components of the ICRG base. These include: (i) stability of government (GOVT_STABILITY_ICRG; which measures the government's ability to drive its agenda and stay in power); (ii) internal conflicts (INTERN_CONFL_ICRG; capture political violence in a country and its real or potential impact on governance); (iii) External conflicts (EXTERN_CONFL_ICRG; measure the risk incurred by the government in relation to external actions); (iv) corruption (CORRUPT_ICRG; captures the degree of corruption within the political apparatus); (v) law and order (LAW_ORDER_ICRG; which measures the power and impartiality of the legal system); (vi) ethnic tensions (ETHNI_TENSION_ICR; capture tensions relating to racial divisions, nationality or language within a country); (vii) accountability and democratic participation (DEMO_ACCOUNT_ICRG; the degree of government accountability to its people), (viii) the quality of the bureaucracy (BUREAU_QUAL_ICRG; captures the power and expertise of the bureaucracy in the implementation of public policies) and; (ix) the investment profile (INVEST_PROFIL_ICRG; it is an estimate of the factors affecting the decision to invest, and which are not taken into account by the other components of political, economic and financial risks. It includes 3 sub -components: viability of contracts / expropriation; repatriation of profits and; payment terms). The tenth variable chosen is that relating to the protection of private property rights. Initially, the rating scale for variables in the ICRG database varied from one group of variables to another ${ }^{2}$. It has been harmonized so that these different components vary from 0 to 6 , with 6 representing the highest risk and 0 , the absence of risk.

Classic variables of growth and investment models: The economic data used in this context come mainly from two sources: the World Development Indicators database of the World Bank and the World Economic Outlook database of the IMF. In this case, they relate to: (i) the growth rate of GDP as an annual percentage, which makes it possible to capture economic growth, the main dependent variable; (ii) Gross Fixed Capital Formation of the private sector (INVPRIV), measured on an annual basis as a percentage of GDP, which is a proxy for private investment; (iii) the composite variable of the share of trade openness of Squalli and

\footnotetext{
${ }^{2}$ In this case, the variables government stability, investment profile, internal and external conflicts had a rating scale that ranged from 0 to 12; 0 reflecting the highest risk and 12 the lowest risk. The corruption, law and order and ethnic tension variables had a rating scale which varied from 0 to 6 with 0 which signifies the highest risk and 6 , the lowest. Finally, the quality variable of the bureaucracy had a scale that varied from 0 to 4 , the gradation having the same meaning as that of the other variables.
} 
Wilson (2011) ${ }^{3}$ (OPEN_SW), which captures the trade openness; (iv) the external debt stock (EXDBSTOC) which is a proxy for indebtedness. Significant debt increases the risk of confiscation of resources and therefore reduces economic growth. This means that the expected sign for this variable is the negative sign; (v) the real interest rate, which captures the wear cost of the investment; (vi) the liquidity rate (M2 / GDP ratio) which reflects the level of development of the financial sphere (DEV_FIN) insofar as a low degree of monetization of the economy is the result of a high level of sophistication of the financial system, which allows individuals to hold less money; (vii) the School Enrollment-Secondary enrollment rate, which is a proxy for education ${ }^{4}$, is introduced to capture the effects of human capital and; (viii) the population growth rate which is a standard variable in economic growth models.

\subsubsection{Methodology adopted}

\section{a. Construction of composite investment climate indices using the Principal Component Analysis (PCA) method}

The PCA method is a data reduction technique that allows the information contained in a large number of variables to be condensed into a new variable. Overall, it includes three main steps: (i) the choice of factor axes to be used for the construction of the composite index. Only the axes whose eigenvalue is greater than the unit is retained; (ii) the determination of the constituent variables of each main axis. Only the variables whose correlation coefficient with the axis is greater than 0.6 are retained as being significant for the explanation of this axis and; (iii) the

Calculation of the composite index. Each composite index obtained is the weighted average of the main components of its corresponding variables, the weight of which is determined by the share of the variance of the variables explained by each component. This means that this analysis only takes into account the institutional components which have a significant contribution to the construction of the main axis. Also, specific weights are automatically generated for each main variable according to its contribution. This approach thus makes it possible to correct the limit noted in certain previous works which, for the construction of the composite index, proceed by simple summation either of all the institutional variables listed in the database, or of some of them according to their degree of correlation, thus assigning a unique weighting to them, which obscures the fact that these different variables do not participate at the same height in the construction of the factor studied.

Several authors have used this approach for the construction of composite indices. For example, Scully (1992) uses this method to construct indices of political and economic freedom. Subsequently, it is used to build indices of political stability (Alesina et al. 1996; Loayza et al. 1997; Demetriades et al. 1996). One of the main advantages of this method is that it makes it possible to reduce the problems of multicollinearity by using in the same equation, aggregated indices of variables potentially correlated with each other.

The PCA made from the variables in the KKM base highlights the fact that the factorial plane formed by the axes (F1 F2) alone explains, 90.95\% of the total variance of the composite investment climate index obtained according to KKM criteria. Furthermore, observation of the correlation table between the variables in the KKM base and the factors (see the details in the table in Appendix 2) shows that the correlation coefficient of each of these variables with the factor F1 is higher at 0.6. This means that all the variables are well represented on this axis which adequately summarizes the index of the investment climate according to KKM. This index is the weighted average of seven (07) variables, the first six (06) of which come from the KKM base and the last, from the Fraser Institute base. These variables are recorded in the table below with their different weights generated in the context of the PCA:

\section{Table 1: Variables of the KKM base retained by the PCA}

\footnotetext{
${ }^{3}$ This variable was constructed following the criticisms they made against the variable traditionally used to capture trade openness, namely, the sum of a country's imports and exports compared to its GDP, and which according to them, only took into account one dimension of trade openness - the degree of trade openness - thus neglecting the second - a country's relative contribution to the volume of world trade - which, in turn, reflects the interaction and the interconnectivity of a country to the rest of the world.

${ }^{4}$ The primary and higher enrollment rates were withdrawn because a significant amount of data was missing to sufficiently inform this variable.
} 


\begin{tabular}{|c|c|c|}
\hline Variable & Description & $\begin{array}{l}\text { Weighting coefficients } \\
\text { generated by the PCA }\end{array}$ \\
\hline VOICE_ACCOUNT_KKM & $\begin{array}{l}\text { Expression and democratic } \\
\text { accountability }\end{array}$ & 0,12058 \\
\hline POL_STABIL_ABS_VIOLENCE_KKM & $\begin{array}{l}\text { Political stability and } \\
\text { absence of violence }\end{array}$ & 0,09857 \\
\hline GOV_EFFECTIV_KKM & Government effectiveness & 0,12376 \\
\hline REGUL_QUAL_KKM & $\begin{array}{l}\text { Quality of administrative } \\
\text { regulations }\end{array}$ & 0,12427 \\
\hline RUL_LAW_KKM & Rule of law & 0,12419 \\
\hline CONTROL_CORRUPT_KKM & Corruption control & 0,12096 \\
\hline RIGHTS_FI & $\begin{array}{l}\text { Protection of private } \\
\text { property rights. }\end{array}$ & 0,11159 \\
\hline
\end{tabular}

\section{Source: Author from the PCA}

Regarding the ICRG base, the factorial plan composed of the axes F1 and F2 explains 69.856\% of the cumulative variability of the composite investment climate index (see the distribution of the factorial axes according to the ICRG criteria recorded in the table in Annex 3).

The criterion of the degree of correlation with the factorial axes made it possible to retain ten (10) variables from the angle of ICRG (see details in the table in Appendix 4) for the construction of the second composite investment climate index. These variables and their weighting coefficients generated by the PCA are listed in the table below:

Table 2: Variables of the ICRG base retained by the PCA

\begin{tabular}{|l|l|l|}
\hline Variables & Description & $\begin{array}{l}\text { Weighting coefficients generated by the } \\
\text { CPA }\end{array}$ \\
\hline GOVT_STABILITY_ICRG & Government stability & 0,02118 \\
\hline INTERN_CONFL_ICRG & Internal conflicts & 0,08482 \\
\hline EXTERN_CONFL_ICRG & External conflicts & 0,05488 \\
\hline CORRUPT_ICRG & Corruption & 0,05391 \\
\hline LAW_ORDER_ICRG & Law and Order & 0,05369 \\
\hline ETHNI_TENSION_ICR & Ethnic tensions & 0,0802 \\
\hline DEMO_ACCOUNT_ICRG & Voice and Accountability & 0,07907 \\
\hline BUREAU_QUAL_ICRG & Quality of the bureaucracy & 0,05157 \\
\hline INVEST_PROFIL_ICRG & Investment profile & 0,0943 \\
\hline RIGHTS_FI & $\begin{array}{l}\text { Protection of private property } \\
\text { rights }\end{array}$ & 0,10688 \\
\hline
\end{tabular}

\section{Source: Author from the PCA}

\section{b. For the estimation of the main model}

The modeling used is based on the work of Poirson (1998) and Nawaz et al. (2014). In this case, the double dimension of the data led to tests to determine whether the structure of this data lends itself to regression in panel data; which has been confirmed. Our approach is to assess the direct and indirect effects of the investment climate on economic growth. The direct effects are captured by the introduction of the investment climate variable in the growth model (we observe these effects in the absence and in the presence 
of the private investment variable). As for indirect effects, they are captured from the private investment model; the latter variable being, according to the results of theoretical and empirical work, a major determinant of economic growth. Equations (1) and (2) below, which are a formalization of the above, are constructed on the basis of standard specifications used in empirical work on the determinants of economic growth and private investment ${ }^{5}$ :

GDPGROWTH $_{i t}=\alpha_{1} P O P \_G R O W T H_{i t}+\alpha_{2} I N V P R I V_{i t}+\alpha_{3} E X D B S T O C_{i t}+\alpha_{4} O P E N_{2} S W_{i t}+$ $\alpha_{5} D E V_{-}$FIN $_{i t}+\alpha_{6} C I V_{i t}+\alpha_{i}+\alpha_{t}+\varepsilon_{i t}(1)$

$I N V P R I V_{i t}=\beta_{1} O P E N_{-} S W_{i t}+\beta_{2} R E A L_{-} I N T E R E S T_{i t}+\beta_{3} D E V_{-} F_{i t}+\beta_{4} C_{i t}+\beta_{5} E_{i t} D B S T O C_{i t}+$ $\beta_{6} S C H O O L \_S E C_{i t}+\beta_{i}+\beta_{t}+v_{i t}$

where $i(i=1 \ldots . .21)$ represents the index of a given SSA country; $t(t=1996 \ldots . .2014)$ the year of observation; GDPGROWTH,GDP growth rate; POP_GROWTH, the rate of population growth; INVPRIV, gross fixed capital formation in the private sector, which is a proxy for private investment; EXDBSTOC, the stock of external debt; OPEN_SW, trade openness according to Squalli and Wilson; $D E V_{-} F I N$, financial development (captured by the ratio $M 2 / P I B$ ); $C I V$ which represents the investment climate variable (it can be one of the individual components of the KKM or ICRG databases or one of the two composite investment climate variables constructed from these databases); $S C H O O L_{-} S E C$ which is the secondary school enrollment rate (which is a proxy for human capital); REAL_INTEREST the real interest rate (which is an inverse function of private investment); $\alpha_{i} ; \beta_{i}$, et $\alpha_{t} ; \beta_{t}$ are the country and time specific effects not observed, respectively, in growth and private investment models; $\varepsilon_{i t}$ et $v_{i t}$ are the error terms (white noise) of the economic growth and investment models respectively. Taking these effects into account is necessary because, if they were to be correlated with the exogenous variables of the model, their omission could bias the estimates.

First, we are interested in the variables of the investment climate of the KKM base. In order to avoid the problem of multicollinearity given the correlation between the variables, we introduce individually, the variables of this base including the composite variable of the investment climate constructed by the PCA method.

In a second step, we are interested in the variables of the ICRG base and the same approach is adopted. It is important to emphasize that the idea is not to make a comparison of the results obtained from the two databases (especially with regard to the parameters) because, even if we can note some similarities between all these variables, however, they are not identical. The concept of investment climate being broad, it is rather a question of capturing the impact (positive or negative) of its different configurations (individual or composite) on economic growth. However, when necessary, comparisons are made when dealing with the same database.To do this, and in order to use the appropriate estimation methods, Hausman specification tests are carried out, which determine the choice between a fixed effect model and a random effect model. Equations (1) and (2) are estimated separately.

\section{Result and discussions}

\subsection{According to the criteria of WGI database (KKM)}

Table 3: Impact of investment climate on economic growth according to the KKM criteria

\section{Dependent variable: GDPGROWTH}

\begin{tabular}{|l|l|l|l|l|l|l|l|}
\hline & $(1)$ & $(2)$ & $(3)$ & $(4)$ & $(5)$ & $(6)$ & $(7)$ \\
\hline Estima & F.E $^{6}$ & R.E & R.E & F.E & F.E & F.E & F.E \\
\hline
\end{tabular}

\footnotetext{
${ }^{5}$ For work on the determinants of economic growth, see Sala-I-Martin (1997); Easterly et al. (1997), Ghura and Hadjimichael (1996), etc. For those relating to private investment, see Servén (1997); Ghura and Goodwin (1997) and Hadjimichael and Ghura (1995).

${ }^{6}$ Fixed effects model

${ }^{7}$ Random effects models
} 


\begin{tabular}{|c|c|c|c|c|c|c|c|}
\hline \multicolumn{8}{|l|}{\begin{tabular}{|l|} 
tion \\
method \\
\end{tabular}} \\
\hline & $\begin{array}{l}\text { CL_INV } \\
\text { EST_KK } \\
\mathrm{M} \\
\end{array}$ & $\begin{array}{l}\text { VOICE_AC } \\
\text { COUNT_K } \\
\text { KM } \\
\end{array}$ & $\begin{array}{l}\text { POL_STABIL_A } \\
\text { BS_VIOLENCE_ } \\
\text { KKM }\end{array}$ & $\begin{array}{l}\text { GOV_EFF } \\
\text { ECTIV_K } \\
\text { KM } \\
\end{array}$ & $\begin{array}{l}\text { REGUL_- } \\
\text { QUAL_K } \\
\text { KM }\end{array}$ & $\begin{array}{l}\text { RUL_L } \\
\mathrm{AW}_{-} \mathrm{K} \\
\mathrm{KM}\end{array}$ & $\begin{array}{l}\text { CONTROL_- } \\
\text { CORRUPT_K } \\
\text { KM }\end{array}$ \\
\hline \multirow[t]{2}{*}{ CIV } & $2.232 * * *$ & $1.349 * *$ & $1.372 * * *$ & 1.864 & $2.750 * *$ & $2.146^{*}$ & $2.920 * * *$ \\
\hline & $(0.400)$ & $(0.684)$ & $(0.420)$ & $(1.189)$ & $(1.128)$ & (1.297) & $(0.987)$ \\
\hline \multirow[t]{2}{*}{$\begin{array}{l}\text { POP_G } \\
\text { ROWT } \\
\text { H }\end{array}$} & $1.512 * * *$ & $-1.535 * * *$ & $-1.460 * * *$ & $-1.679 * * *$ & $-1.695 * * *$ & $\begin{array}{l}- \\
1.784 * *\end{array}$ & $-1.567 * * *$ \\
\hline & $(0.486)$ & $(0.433)$ & $(0.430)$ & $(0.493)$ & $(0.479)$ & $(0.479)$ & $(0.483)$ \\
\hline \multirow{2}{*}{$\begin{array}{l}\text { OPEN_ } \\
\text { SW }\end{array}$} & $0.0876^{*}$ & 0.0538 & 0.0488 & $0.105 * *$ & 0.0583 & $0.0976^{*}$ & $0.122 * *$ \\
\hline & $(0.0524)$ & $(0.0379)$ & $(0.0379)$ & $(0.0525)$ & $(0.0565)$ & $(0.0530)$ & $(0.0520)$ \\
\hline \multirow[t]{2}{*}{$\begin{array}{l}\text { EXDB } \\
\text { STOC }\end{array}$} & $\begin{array}{l}- \\
0.00196 * \\
*\end{array}$ & $-0.00205^{* *}$ & $-0.00171 * *$ & $\begin{array}{l}- \\
0.00259 * * \\
*\end{array}$ & $\begin{array}{l}- \\
0.00238 * * \\
*\end{array}$ & $\begin{array}{l}- \\
0.00227 \\
* * *\end{array}$ & $-0.00277 * * *$ \\
\hline & $\begin{array}{l}(0.00081 \\
2)\end{array}$ & $(0.000797)$ & (0.000797) & $(0.000794)$ & $\begin{array}{l}(0.000795 \\
)\end{array}$ & $\begin{array}{l}(0.0008 \\
17)\end{array}$ & $(0.000790)$ \\
\hline \multirow[t]{2}{*}{$\begin{array}{l}\text { INVPR } \\
\text { IV }\end{array}$} & $\begin{array}{l}2.0208 * * \\
*\end{array}$ & $2.00624 * * *$ & $2.0360 * * *$ & $2.0197 * * *$ & $2.0133 * * *$ & $\begin{array}{l}2.0288^{*} \\
* *\end{array}$ & $2.0166^{* * *}$ \\
\hline & $(0.0439)$ & $(0.0420)$ & $(0.0425)$ & $(0.0450)$ & $(0.0447)$ & $(0.0442)$ & $(0.0441)$ \\
\hline \multirow{2}{*}{$\begin{array}{l}\text { DEV_F } \\
\text { IN }\end{array}$} & 0.0531 & 0.0484 & $0.0531 *$ & 0.0479 & 0.0326 & $0.0613 *$ & 0.0479 \\
\hline & $(0.0351)$ & $(0.0319)$ & $(0.0315)$ & $(0.0360)$ & $(0.0367)$ & $(0.0354)$ & $(0.0352)$ \\
\hline \multirow{2}{*}{$\begin{array}{l}\text { Consta } \\
\text { nt }\end{array}$} & 1.271 & 1.317 & 1.273 & 1.178 & 1.182 & 1.284 & 1.843 \\
\hline & $(2.091)$ & $(2.082)$ & $(1.975)$ & $(2.323)$ & $(2.141)$ & $(2.324)$ & $(2.167)$ \\
\hline $\begin{array}{l}\text { Observ } \\
\text { ations }\end{array}$ & 365 & 365 & 365 & 365 & 365 & 365 & 365 \\
\hline $\begin{array}{l}\text { Numbe } \\
r \text { of ID }\end{array}$ & 21 & 21 & 21 & 21 & 21 & 21 & 21 \\
\hline $\begin{array}{l}\text { R- } \\
\text { square } \\
\text { d }\end{array}$ & 0.635 & - & - & 0.617 & 0.626 & 0.618 & 0.633 \\
\hline
\end{tabular}

Source: Author from the secondary databases used

Table 4: Perspective of indirect impact of investment climate on economic growth according to the KKM criteria

Dependent variable : GDPGROWTH

\begin{tabular}{l|l|l}
$(1)$ & $(2)$ & $(3)$ \\
\hline
\end{tabular}

(4)

$(5)$

(6)

(7) 


\begin{tabular}{|c|c|c|c|c|c|c|c|}
\hline Estimat & R.E & R.E & R.E & F.E & F.E & F.E & F.E \\
\hline & $\begin{array}{l}\text { CL_INV } \\
\text { EST_KK } \\
\mathrm{M}\end{array}$ & $\begin{array}{l}\text { VOICE_AC } \\
\text { COUNT_K } \\
\mathrm{KM}\end{array}$ & $\begin{array}{l}\text { POL_STABIL_AB } \\
\text { S_VIOLENCE_K } \\
\text { KM }\end{array}$ & $\begin{array}{l}\text { GOV_EFF } \\
\text { ECTIV_K } \\
\text { KM }\end{array}$ & $\begin{array}{l}\text { REGUL_- } \\
\text { QUAL_K } \\
\text { KM }\end{array}$ & $\begin{array}{l}\text { RUL_L } \\
\text { AW_KK } \\
M\end{array}$ & $\begin{array}{l}\text { CONTROL } \\
\text { _CORRUPT } \\
\text { _KKM }\end{array}$ \\
\hline \multirow[t]{2}{*}{ CIV } & $2.435^{* * *}$ & $1.341 * *$ & $1.294 * * *$ & $1.966^{*}$ & $2.812 * *$ & $2.200 *$ & $2.968 * * *$ \\
\hline & $(0.389)$ & $(0.676)$ & $(0.409)$ & $(1.165)$ & $(1.107)$ & $(1.293)$ & $(0.977)$ \\
\hline \multirow[t]{2}{*}{$\begin{array}{l}\text { POP_G } \\
\text { ROWT } \\
\mathrm{H}\end{array}$} & - & $-1.522 * * *$ & $-1.440 * * *$ & $-1.648 * * *$ & $-1.677 * * *$ & $\begin{array}{l}- \\
1.750 * * \\
*\end{array}$ & $-1.544 * * *$ \\
\hline & $(0.404)$ & $(0.429)$ & $(0.428)$ & $(0.487)$ & $(0.475)$ & $(0.476)$ & $(0.479)$ \\
\hline \multirow{2}{*}{$\begin{array}{l}\mathrm{OPEN}_{-} \\
\mathrm{SW}\end{array}$} & 0.0310 & 0.0512 & 0.0402 & $0.0980 * *$ & 0.0523 & $0.0865 *$ & $0.116 * *$ \\
\hline & $(0.0300)$ & $(0.0359)$ & $(0.0360)$ & $(0.0496)$ & $(0.0527)$ & $(0.0502)$ & $(0.0495)$ \\
\hline \multirow[t]{2}{*}{$\begin{array}{l}\text { EXDB } \\
\text { STOC }\end{array}$} & $\begin{array}{l}- \\
0.00145^{*} \\
*\end{array}$ & $-0.00208 * * *$ & $-0.00195 * * *$ & $\begin{array}{l}- \\
0.00271 * * *\end{array}$ & $\begin{array}{l}- \\
0.00245 * * \\
*\end{array}$ & $\begin{array}{l}- \\
0.00243 \\
* * *\end{array}$ & $-0.00287 * * *$ \\
\hline & $\begin{array}{l}(0.00073 \\
8)\end{array}$ & $(0.000750)$ & $(0.000736)$ & $(0.000749)$ & $(0.000755)$ & $\begin{array}{l}(0.00077 \\
6)\end{array}$ & $(0.000741)$ \\
\hline \multirow{2}{*}{$\begin{array}{l}\text { DEV_F } \\
\text { IN }\end{array}$} & 0.0303 & 0.0478 & 0.0492 & 0.0446 & 0.0302 & 0.0573 & 0.0454 \\
\hline & $(0.0287)$ & $(0.0315)$ & $(0.0311)$ & $(0.0352)$ & $(0.0358)$ & $(0.0348)$ & $(0.0345)$ \\
\hline \multirow{2}{*}{$\begin{array}{l}\text { Consta } \\
\mathrm{nt}\end{array}$} & 1.455 & 1.407 & 1.600 & 1.495 & 1.370 & 1.662 & 2.071 \\
\hline & $(1.741)$ & $(2.015)$ & $(1.930)$ & $(2.205)$ & $(2.042)$ & $(2.249)$ & $(2.078)$ \\
\hline $\begin{array}{l}\text { Observ } \\
\text { ations }\end{array}$ & 365 & 365 & 365 & 365 & 365 & 365 & 365 \\
\hline $\begin{array}{l}\text { Numbe } \\
\mathrm{r} \text { of ID }\end{array}$ & 21 & 21 & 21 & 21 & 21 & 21 & 21 \\
\hline $\begin{array}{l}\text { R- } \\
\text { squared }\end{array}$ & - & - & - & 0.597 & 0.586 & 5.817 & 5.933 \\
\hline
\end{tabular}

\section{Source: Author from the secondary databases used}

The observation of tables 3 and 4 allows us to make the following analyzes:

- overall, all the variables show the expected economic signs;

- in columns 1 of these two tables, we see that the investment climate composite variable, CL_INVEST_KKM (measured as an aggregate factorial index of democracy, political stability and the absence of violence / terrorism, efficiency of public governance, the quality of administrative regulations, rule of law, corruption control and security of private property rights), has a direct positive and significant impact at $1 \%$ level, on economic growth. In this case, an improvement in the quality of the investment climate of a unit, leads, all other things being equal, to an increase in the economic growth rate by a 
percentage which varies between $2.232 \%$ and $2.435 \%$. This result confirms the trends that were already emerging from the above-developed analysis, on the evolution of the relationship between GDP per capita and index of ease of doing business, and which suggested a positive link between the climate of investment and economic growth. More so, it is similar to the results of numerous authors who have shown that the investment climate variable, constructed on the basis of various and different components, has a positive and significant impact on economic growth. In this context, we can cite Valeriani et al. (2011) who, using panel data estimates, showed that the quality of the investment climate, measured by the aggregation of three groups of variables (the civil liberties of Freedom House, the quality of government, built on the bureaucracy, corruption and stability components of ICRG, and the legislative checks and balances of the Political Institutions Database), had a significant and positive impact on economic growth for both developed and developing countries. Similarly, Brunetti et al. (1997) show that the credibility index (constructed as an average of predictability in the formalization of rules, of the perception of political stability, of security of persons and of property, of the predictability of the judicial system and of the corruption) positively influences economic growth. Furthermore, we note that the impact of the investment climate on economic growth in the absence of the private investment variable $(2.435 \%)$ is greater than that obtained in the presence of this variable $(2.232 \%)$. This may be an indicator that beyond having a direct impact on economic growth, the quality of the investment climate acts indirectly, through its effects on private investment (which are estimated in the private investment model from which this analysis will be verified). Thus, part of the effects of the investment climate on economic growth would be absorbed in the presence of the private investment variable in the model;

- the estimate of the specific components of the investment climate, taken individually in the model, shows that the corruption control variable (CONTROL_CORRUPT_KKM) is significant at $1 \%$ in both models and presents the highest (positive) impact. We note in particular that an improvement in the control of corruption in a unit, all other things being equal, translates into an increase in the economic growth rate of a scale which varies between $2.920 \%$ and $2.968 \%$ (columns 7 of the previous tables). This shows that corruption has negative effects on the economic performance of SSA countries, and that combating it must be a major focus of the development strategy of these countries. Similar results with few exceptions, were obtained by Mauro (1995), who finds that corruption has an indirect effect on economic growth, by reducing private investment. According to Guetat (2006), corruption deteriorates economic growth more significantly in countries of the MENA region than in those of Latin America and other regions. In the same vein, Mo (2000) finds that a $1 \%$ increase in the level of corruption reduces the economic growth rate by $0.72 \%$;

- The variable political stability and absence of violence/terrorism (POL_STABIL_ABS_VIOLENCE_KKM) has a positive and significant impact at $1 \%$ level on economic growth (columns 3 of the previous tables), with however, a smaller magnitude when the variable private investment is removed from model (1.294 versus 1.372). Such a result may reflect the preponderance of direct effects over indirect effects of this variable, on economic growth. The positive impact of political stability (or, conversely, the negative impact of political instability) on economic growth is a result found in those of many economists who have worked in the field. In this case, Alesina et al. (1996) show that political instability, captured by the occurrence of coups, has a significant and negative impact on the economic growth of the countries where it takes place. Gyimah-Brempong (1995), through a panel of 38 African countries over the period 1975-1988, shows that political instability, measured not only by changes or attempts to change the leaders (coups, plots, etc. .), but also through events such as strikes, demonstrations, etc., has a significant and negative impact on economic growth;

- The Government Efficiency variable (GOV_EFFECTIV_KKM) seems to have only an indirect impact on economic growth. Indeed, it is not significant in the presence of the variable INVPRIV (column 4 of table 3), and significant (at 10\%) when the latter is removed from the model (column 4 of table 4); $\backslash$

- The variable Voice and Accountability, which is an indicator of democracy, has a positive and significant impact (at 5\%) on economic growth. In addition, we note that the impact is greater in the presence of the investment variable ( $1.349 \%$ in column 2 of table 3$)$ than in its absence $(1.341 \%$ in column 2 of table 4); possibly reflecting the fact that democracy can have not only a direct effect on economic growth but also an indirect impact through the channel of private investment. It must be said that this result is an additional contribution to the still topical debate, on the real impact of democracy on the economic 
performance of states. Very little work has come to the conclusion of a positive impact of democracy on economic growth;

- The rule of law variable also has a positive and significant impact (however at only 10\%) on economic growth. In particular, an improvement in the score for the rule of law variable leads, all other things being equal, to an increase in the growth rate by a percentage that varies between $2.146 \%$ and $2.2 \%$ (columns 6 of tables 3 and 4); thus joining the conclusions of Barro and Sala-I-Martin (1995) who, after checking a variety of instruments in the institutional environment, find that the rules and laws component has a positive and significant impact on economic growth;

- The variable private investment (INVPRIV), introduced into the equations in table 3 , has a positive and significant impact at $1 \%$, in each of them. This confirms the economic analysis which is generally made and according to which investment is a major determinant of economic growth;

- - The variables trade openness (OPEN_SW) and financial development (DEV_FIN) have a mixed direct impact on economic growth. Indeed, they are significant (at 5\% at most) in some equations (in very few in terms of financial development) and not significant in others.

In order to assess the indirect impact of the investment climate and / or its components on economic growth, estimates of private investment models were made, the results of which are shown in the tables below:

Table 5: Indirect impact of investment climate on economic growth according to the KKM criteria: the private investment channel

\begin{tabular}{|c|c|c|c|c|c|c|c|c|}
\hline & \multicolumn{8}{|c|}{ Dependent variable : INVPRIV } \\
\hline & $(1)$ & $(2)$ & (3) & $(4)$ & $(5)$ & $(6)$ & $(7)$ & $(8)$ \\
\hline \multirow{2}{*}{$\begin{array}{l}\text { Estimat } \\
\text { ion } \\
\text { method }\end{array}$} & \multicolumn{8}{|c|}{ Modèle à effets fixes } \\
\hline & $\begin{array}{l}\text { CL_IN } \\
\text { VEST_- } \\
\text { KKM } \\
\end{array}$ & $\begin{array}{l}\text { RIG } \\
\text { HTS } \\
\text { _FI }\end{array}$ & $\begin{array}{l}\text { VOICE_A } \\
\text { CCOUNT_- } \\
\text { KKM } \\
\end{array}$ & $\begin{array}{l}\text { POL_STABIL_A } \\
\text { BS_VIOLENCE } \\
\text { KKM }\end{array}$ & $\begin{array}{l}\text { GOV_EFF } \\
\text { ECTIV_K } \\
\text { KM } \\
\end{array}$ & $\begin{array}{l}\text { REGUL_- } \\
\text { QUAL_K } \\
\text { KM } \\
\end{array}$ & $\begin{array}{l}\text { RUL_L } \\
\text { AW_K } \\
\text { KM }\end{array}$ & $\begin{array}{l}\text { CONTRO } \\
\text { L_CORRU } \\
\text { PT_KKM } \\
\end{array}$ \\
\hline \multirow[t]{2}{*}{ CIV } & $\begin{array}{l}2.776 * * \\
*\end{array}$ & $\begin{array}{l}1.43 \\
4 * * *\end{array}$ & $3.953 * * *$ & $1.589 * * *$ & $6.187 * * *$ & $5.706^{* * *}$ & $\begin{array}{l}5.026 * * \\
*\end{array}$ & $4.183 * * *$ \\
\hline & $(0.459)$ & $\begin{array}{l}(0.32 \\
2) \\
\end{array}$ & $(1.046)$ & $(0.589)$ & $(1.305)$ & $(1.210)$ & $(1.342)$ & $(1.076)$ \\
\hline \multirow[t]{2}{*}{$\begin{array}{l}\text { OPEN_ } \\
\text { SW }\end{array}$} & $\begin{array}{l}0.342 * * \\
* \\
\end{array}$ & $\begin{array}{l}0.36 \\
0 * * *\end{array}$ & $0.322 * * *$ & $0.263 * * *$ & $0.315^{* * *}$ & $0.390 * * *$ & $\begin{array}{l}0.336 * * \\
*\end{array}$ & $0.287 * * *$ \\
\hline & $(0.0640)$ & $\begin{array}{l}(0.06 \\
13)\end{array}$ & $(0.0637)$ & $(0.0670)$ & $(0.0630)$ & $(0.0651)$ & $\begin{array}{l}(0.0640 \\
\end{array}$ & $(0.0640)$ \\
\hline \multirow[t]{2}{*}{$\begin{array}{l}\text { EXDBS } \\
\text { TOC }\end{array}$} & $\begin{array}{l}- \\
0.00592 \\
* * *\end{array}$ & $\begin{array}{l}- \\
0.00 \\
692 * \\
* *\end{array}$ & $\begin{array}{l}- \\
0.00544 * * *\end{array}$ & $-0.00836^{* * *}$ & $\begin{array}{l}- \\
0.00650 * * \\
*\end{array}$ & $\begin{array}{l}- \\
0.00590 * \\
* *\end{array}$ & $\begin{array}{l}- \\
0.00602 \\
* * *\end{array}$ & $\begin{array}{l}- \\
0.00680 * * \\
*\end{array}$ \\
\hline & $\begin{array}{l}(0.0010 \\
0)\end{array}$ & $\begin{array}{l}(0.00 \\
0920 \\
)\end{array}$ & $(0.00106)$ & $(0.00103)$ & $(0.000943$ & (0.000973 & $\begin{array}{l}(0.0009 \\
96)\end{array}$ & $(0.000946)$ \\
\hline \multirow[t]{2}{*}{$\begin{array}{l}\text { REAL_- } \\
\text { INTER } \\
\text { EST }\end{array}$} & $\begin{array}{l}- \\
0.0657 * \\
* *\end{array}$ & $\begin{array}{l}- \\
0.03 \\
24\end{array}$ & $-0.0648 * * *$ & $-0.0550 * *$ & $-0.0579 * *$ & $\begin{array}{l}- \\
0.0720 * * \\
*\end{array}$ & $\begin{array}{l}- \\
0.0591 * \\
*\end{array}$ & $-0.0571 * *$ \\
\hline & $(0.0241)$ & \begin{tabular}{|l}
$(0.02$ \\
$33)$ \\
\end{tabular} & $(0.0242)$ & $(0.0244)$ & $(0.0239)$ & $(0.0240)$ & $\begin{array}{l}(0.0241 \\
)\end{array}$ & $(0.0241)$ \\
\hline
\end{tabular}




\begin{tabular}{|c|c|c|c|c|c|c|c|c|}
\hline $\begin{array}{l}\text { DEV_F } \\
\text { IN }\end{array}$ & $\begin{array}{l}0.252 * * \\
*\end{array}$ & $\begin{array}{l}0.21 \\
6 * * * \\
\end{array}$ & $0.252 * * *$ & $0.272 * * *$ & $0.268 * * *$ & $0.277 * * *$ & $\begin{array}{l}0.227 * * \\
*\end{array}$ & $0.251 * * *$ \\
\hline & $(0.0422)$ & $\begin{array}{l}(0.04 \\
45) \\
\end{array}$ & $(0.0422)$ & $(0.0427)$ & $(0.0417)$ & $(0.0418)$ & $\begin{array}{l}(0.0431 \\
) \\
\end{array}$ & $(0.0422)$ \\
\hline \multirow{2}{*}{$\begin{array}{l}\text { SCHO } \\
\text { OL_SE } \\
\text { C }\end{array}$} & $\begin{array}{l}0.133 * * \\
*\end{array}$ & $\begin{array}{l}0.13 \\
2 * * *\end{array}$ & $0.139 * * *$ & $0.158 * * *$ & $0.120 * * *$ & $0.116^{* * *}$ & $\begin{array}{l}0.121 * * \\
*\end{array}$ & $0.113 * * *$ \\
\hline & $(0.0306)$ & $\begin{array}{l}(0.02 \\
96) \\
\end{array}$ & $(0.0306)$ & $(0.0316)$ & $(0.0306)$ & $(0.0307)$ & $\begin{array}{l}(0.0310 \\
)\end{array}$ & $(0.0314)$ \\
\hline \multirow[t]{2}{*}{$\begin{array}{l}\text { Constan } \\
\mathbf{t}\end{array}$} & $\begin{array}{l}15.50 * * \\
*\end{array}$ & $\begin{array}{l}11.2 \\
0 * * *\end{array}$ & $17.52 * * *$ & $15.08 * * *$ & $18.81^{* * *}$ & $17.73 * * *$ & $\begin{array}{l}19.22 * * \\
*\end{array}$ & $17.10 * * *$ \\
\hline & $(1.329)$ & $\begin{array}{l}(1.59 \\
1) \\
\end{array}$ & (1.418) & $(1.359)$ & $(1.475)$ & (1.388) & (1.635) & $(1.379)$ \\
\hline $\begin{array}{l}\text { Observ } \\
\text { ations }\end{array}$ & 399 & 365 & 399 & 399 & 399 & 399 & 399 & 399 \\
\hline $\begin{array}{l}\text { R- } \\
\text { squared }\end{array}$ & 0.711 & $\begin{array}{l}0.70 \\
7 \\
\end{array}$ & 0.710 & 0.797 & 0.724 & 0.724 & 0.710 & 0.712 \\
\hline $\begin{array}{l}\text { Number } \\
\text { of ID }\end{array}$ & 21 & 21 & 21 & 21 & 21 & 21 & 21 & 21 \\
\hline
\end{tabular}

\section{Source: Author from secondary databases}

In light of the analyzes that have been made previously on the impact of the investment climate on economic growth, the observation in table 5 above suggests the following comments:

- All components of the investment climate, including the composite variable, have a very significant (1\%) and positive effect on private investment. This means that apart from the variables of government efficiency (GOV_EFFECTIV_KKM) and protection of private property rights (RIGHTS_FI), which only have an indirect influence on economic growth, in particular through the investment channel private, all other variables of the investment climate have a direct and indirect impact on it;

- The government efficiency variable has the highest indirect impact on economic growth $(6.187 \%)$ while the corruption control variable has the highest direct influence on it;

- The direct and indirect positive impact of the democracy variable (VOICE_ACCOUNT_KKM) on economic growth, was also observed in the work of Poirson (1998), Hadjimichael and Ghura (1995) and Kormendi and Megoulez (1985);

- The variables trade openness (OPEN_SW) and financial development (DEV_FIN) whose direct effects on economic growth were mixed, exert on it, a very significant indirect influence (at $1 \%$ ) via private investment, with respective average impacts estimated as a percentage of GDP at $0.327 \%$ and $0.252 \%$. This result is similar to that obtained by Poirson (1998);

- The variable SCHOOL_SEC (enrollment rate in secondary education), which is a proxy for human capital, has a significant $(1 \%)$ and indirect positive impact on economic growth, estimated on average at 0.129\%. This result stands out from that obtained by Poirson (1998), which found a positive but not significant impact. This means that the quality of human capital is an important factor for investors;

- The real interest rate, which captures the cost of wearing down capital, shows the expected negative sign. 
Overall, the results obtained from the KKM database show that the investment climate, measured by its specific components or even by a linear combination of them, has a direct and indirect positive impact on economic growth.

3.2 Robustness check: estimates according to ICRG criteria

Table 6. Direct impact of investment climate on economic growth according to the ICRG criteria Dependent variable : GDPGROWTH

\begin{tabular}{|c|c|c|c|c|c|c|c|c|c|c|}
\hline & $(1)$ & $(2)$ & (3) & (4) & $(5)$ & (6) & $(7)$ & $(8)$ & (9) & $(10)$ \\
\hline \multirow{2}{*}{$\begin{array}{l}\text { Esti } \\
\text { mati } \\
\text { on } \\
\text { meth } \\
\text { od }\end{array}$} & F.E & R.E & R.E & R.E & R.E & R.E & R.E & R.E & R.E & R.E \\
\hline & $\begin{array}{c}\text { CL_IN } \\
\text { VEST } \\
\text { _ICRG }\end{array}$ & $\begin{array}{l}\text { INTER } \\
\text { N_CON } \\
\text { FL_ICR } \\
\text { G }\end{array}$ & $\begin{array}{l}\text { EXTER } \\
\text { N_CON } \\
\text { FL_ICR } \\
\text { G }\end{array}$ & $\begin{array}{l}\text { COR } \\
\text { RUPT } \\
\text { _ICR } \\
\text { G }\end{array}$ & $\begin{array}{l}\mathrm{LAW}_{-} \\
\text {ORDE } \\
\text { R_ICR } \\
\text { G }\end{array}$ & $\begin{array}{l}\text { ETHNI_ } \\
\text { TENSI } \\
\text { ON_IC } \\
\mathrm{R}\end{array}$ & $\begin{array}{l}\text { DEMO_} \\
\text { ACCOU } \\
\text { NT_ICR } \\
\text { G }\end{array}$ & $\begin{array}{l}\text { BUREA } \\
\text { U_QUA } \\
\text { L_ICRG }\end{array}$ & $\begin{array}{l}\text { GOVT_S } \\
\text { TABILIT } \\
\text { Y_ICRG }\end{array}$ & $\begin{array}{l}\text { INVE } \\
\text { ST_P } \\
\text { ROFI } \\
\text { L_ICR } \\
\text { G }\end{array}$ \\
\hline \multirow[t]{2}{*}{ CIV } & $1.165^{*}$ & $0.358 * *$ & $0.464 * *$ & $\begin{array}{l}0.453 \\
*\end{array}$ & $0.560 *$ & $0.350 * *$ & $0.431 *$ & $0.264 * *$ & $0.348 * *$ & $0.275^{*}$ \\
\hline & $\begin{array}{l}(0.621 \\
) \\
\end{array}$ & $(0.179)$ & $(0.218)$ & $\begin{array}{l}(0.250 \\
) \\
\end{array}$ & $(0.300)$ & $(0.140)$ & $(0.257)$ & $(0.107)$ & $(0.160)$ & $\begin{array}{l}(0.155 \\
\end{array}$ \\
\hline \multirow{2}{*}{$\begin{array}{l}\text { POP } \\
\text { GRR } \\
\text { OW } \\
\text { TH } \\
\end{array}$} & $\begin{array}{l}- \\
1.705 * \\
* *\end{array}$ & $\begin{array}{l}- \\
1.496 * * \\
*\end{array}$ & $1.578 * * *$ & $\begin{array}{l}- \\
1.550 \\
* * *\end{array}$ & $\begin{array}{l}- \\
1.564 * \\
* *\end{array}$ & $\begin{array}{l}- \\
1.677 * * \\
*\end{array}$ & 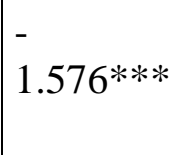 & $\begin{array}{l}- \\
1.556 * * \\
*\end{array}$ & - & $\begin{array}{l}- \\
1.579 * \\
* *\end{array}$ \\
\hline & $\begin{array}{l}(0.484 \\
)\end{array}$ & $(0.433)$ & $(0.430)$ & $\begin{array}{l}(0.432 \\
)\end{array}$ & $(0.434)$ & $(0.434)$ & $(0.418)$ & $(0.419)$ & $(0.425)$ & $(0.431$ \\
\hline \multirow{2}{*}{$\begin{array}{l}\text { OPE } \\
\text { N_S } \\
\text { W } \\
\end{array}$} & $\begin{array}{l}0.0938 \\
*\end{array}$ & 0.0489 & 0.0421 & $\begin{array}{l}0.052 \\
8\end{array}$ & 0.0589 & 0.0534 & 0.0425 & 0.0457 & 0.0371 & 0.0480 \\
\hline & $\begin{array}{l}(0.053 \\
1) \\
\end{array}$ & $(0.0375)$ & $(0.0383)$ & $\begin{array}{l}(0.037 \\
4) \\
\end{array}$ & $\begin{array}{l}(0.0381 \\
) \\
\end{array}$ & $(0.0381)$ & $(0.0349)$ & $(0.0349)$ & $(0.0371)$ & $\begin{array}{l}(0.038 \\
1) \\
\end{array}$ \\
\hline \multirow[t]{2}{*}{$\begin{array}{l}\text { EXD } \\
\text { BST } \\
\text { OC } \\
\end{array}$} & $\begin{array}{l}- \\
0.0020 \\
6 * *\end{array}$ & $\begin{array}{l}- \\
0.00190 \\
* *\end{array}$ & $\begin{array}{l}- \\
0.00203 * \\
*\end{array}$ & $\begin{array}{l}- \\
0.002 \\
77 * * *\end{array}$ & $\begin{array}{l}- \\
0.0024 \\
4 * * *\end{array}$ & $\begin{array}{l}- \\
0.00223 \\
* * *\end{array}$ & $\begin{array}{l}- \\
0.00189 * \\
*\end{array}$ & $\begin{array}{l}- \\
0.00237 \\
* * *\end{array}$ & $\begin{array}{l}- \\
0.00263 * \\
* *\end{array}$ & $\begin{array}{l}- \\
0.0018 \\
9^{* *}\end{array}$ \\
\hline & \begin{tabular}{|l|}
$(0.000$ \\
$842)$ \\
\end{tabular} & $\begin{array}{l}(0.00081 \\
8) \\
\end{array}$ & $\begin{array}{l}(0.00079 \\
5)\end{array}$ & \begin{tabular}{|l}
$(0.000$ \\
$810)$ \\
\end{tabular} & \begin{tabular}{|l}
$(0.0007$ \\
$72)$ \\
\end{tabular} & $\begin{array}{l}(0.0001 \\
0803) \\
\end{array}$ & $\begin{array}{l}(0.00082 \\
4) \\
\end{array}$ & $\begin{array}{l}(0.00077 \\
0) \\
\end{array}$ & $\begin{array}{l}(0.00077 \\
3)\end{array}$ & $\begin{array}{l}(0.000 \\
834) \\
\end{array}$ \\
\hline \multirow{2}{*}{$\begin{array}{l}\text { INV } \\
\text { PRI } \\
\text { V } \\
\end{array}$} & $\begin{array}{l}0.340 * \\
* *\end{array}$ & $\begin{array}{l}0.220 * * \\
*\end{array}$ & $0.114 * *$ & $\begin{array}{l}0.234 \\
* * *\end{array}$ & $\begin{array}{l}0.133 * \\
* *\end{array}$ & $\begin{array}{l}0.671 * * \\
*\end{array}$ & $0.181 * * *$ & $\begin{array}{l}0.452 * * \\
*\end{array}$ & $0.164 * * *$ & $\begin{array}{l}0.191 * \\
* *\end{array}$ \\
\hline & $\begin{array}{l}(0.044 \\
1) \\
\end{array}$ & $(0.0427)$ & $(0.0420)$ & $\begin{array}{l}(0.042 \\
6) \\
\end{array}$ & $\begin{array}{l}(0.0425 \\
)\end{array}$ & $(0.0422)$ & $(0.0418)$ & $(0.0420)$ & $(0.0429)$ & $\begin{array}{l}(0.042 \\
6) \\
\end{array}$ \\
\hline \multirow[t]{2}{*}{$\begin{array}{l}\text { DEV } \\
\text { FIN }\end{array}$} & 0.0536 & 0.0451 & 0.0367 & $\begin{array}{l}0.043 \\
5 \\
\end{array}$ & 0.0386 & 0.0372 & 0.0343 & 0.0345 & 0.0344 & 0.0436 \\
\hline & $(0.035$ & $(0.0315)$ & $(0.0314)$ & $(0.031$ & $(0.0315$ & $(0.0316)$ & $(0.0305)$ & $(0.0304)$ & $(0.0310)$ & $(0.031$ \\
\hline
\end{tabular}




\begin{tabular}{|c|c|c|c|c|c|c|c|c|c|c|}
\hline & 4) & & & 7) & ) & & & & & 6) \\
\hline \multirow{2}{*}{$\begin{array}{c}\text { RIG } \\
\text { HTS } \\
\text { FI }\end{array}$} & 0.367 & $0.642 * *$ & $0.570 * *$ & $\begin{array}{l}0.642 \\
* *\end{array}$ & $\begin{array}{l}0.543 * \\
*\end{array}$ & $0.578 * *$ & $0.564 * *$ & $0.643 * *$ & $0.637 * *$ & $0.506^{*}$ \\
\hline & $\begin{array}{l}(0.284 \\
)\end{array}$ & $(0.256)$ & $(0.255)$ & $\begin{array}{l}(0.258 \\
)\end{array}$ & $(0.258)$ & $(0.257)$ & $(0.251)$ & $(0.252)$ & $(0.254)$ & $\begin{array}{l}(0.260 \\
)\end{array}$ \\
\hline \multirow{2}{*}{$\begin{array}{l}\text { Cons } \\
\text { tant } \\
\end{array}$} & 0.0451 & -3.281 & $-4.698 *$ & -0.853 & -1.659 & -1.518 & -1.404 & 0.0722 & 3.096 & -1.897 \\
\hline & $\begin{array}{l}(2.047 \\
)\end{array}$ & $(2.470)$ & (2.856) & $\begin{array}{l}(1.994 \\
\text { ) }\end{array}$ & $(2.263)$ & $(2.320)$ & $(2.030)$ & (1.864) & $(2.422)$ & $\begin{array}{l}(2.156 \\
)\end{array}$ \\
\hline $\begin{array}{l}\text { Obse } \\
\text { rvati } \\
\text { ons } \\
\end{array}$ & 365 & 365 & 365 & 365 & 365 & 365 & 365 & 365 & 365 & 365 \\
\hline $\begin{array}{l}\text { Num } \\
\text { ber } \\
\text { of ID }\end{array}$ & 21 & 21 & 21 & 21 & 21 & 21 & 21 & 21 & 21 & 21 \\
\hline
\end{tabular}

Table 7: Indirect impact of investment climate on economic growth according to ICRG criteria: the private investment channel

\begin{tabular}{|c|c|c|c|c|c|c|c|c|c|c|c|}
\hline & \multicolumn{11}{|c|}{ Dependent variable : INVPRIV } \\
\hline & $(1)$ & $(2)$ & $(3)$ & $(4)$ & $(5)$ & $(6)$ & $(7)$ & $(8)$ & $(9)$ & $(10)$ & $(11)$ \\
\hline & \multicolumn{11}{|c|}{ Estimation method : Fixed effects } \\
\hline & $\begin{array}{l}\text { CL_IN } \\
\text { VEST } \\
1 \_I C R \\
\text { G }\end{array}$ & $\begin{array}{l}\text { RI } \\
\text { GH } \\
\text { TS } \\
\text { _FI }\end{array}$ & $\begin{array}{l}\text { INTER } \\
\text { N_CON } \\
\text { FL_ICR } \\
\text { G }\end{array}$ & $\begin{array}{l}\text { EXTER } \\
\text { N_CON } \\
\text { FL_ICR } \\
\text { G }\end{array}$ & $\begin{array}{l}\text { COR } \\
\text { RUP } \\
\text { T_IC } \\
\text { RG }\end{array}$ & $\begin{array}{l}\mathrm{LAW}_{-} \\
\text {ORDE } \\
\text { R_ICR } \\
\text { G }\end{array}$ & $\begin{array}{l}\text { ETHNI } \\
\text { _TENSI } \\
\text { ON_IC } \\
\text { RG }\end{array}$ & $\begin{array}{l}\text { DEMO_ } \\
\text { ACCOU } \\
\text { NT_ICR } \\
\text { G }\end{array}$ & $\begin{array}{l}\text { BURE } \\
\text { AU_Q } \\
\text { UAL_I } \\
\text { CRG }\end{array}$ & $\begin{array}{l}\text { GOVT__ } \\
\text { STABIL } \\
\text { ITY_IC } \\
\text { RG }\end{array}$ & $\begin{array}{l}\text { INVE } \\
\text { ST_P } \\
\text { ROFI } \\
\text { L_IC } \\
\text { RG } \\
\end{array}$ \\
\hline \multirow[t]{2}{*}{ CIV } & $\begin{array}{l}1.460 * \\
*\end{array}$ & $\begin{array}{l}1.4 \\
34 * \\
* *\end{array}$ & $\begin{array}{l}0.789 * * \\
*\end{array}$ & 0.283 & $\begin{array}{l}1.174 \\
* * *\end{array}$ & $\begin{array}{l}0.709 * \\
*\end{array}$ & 0.361 & $0.687 * *$ & $\begin{array}{l}0.744 * * \\
*\end{array}$ & $\begin{array}{l}0.517 * * \\
*\end{array}$ & $\begin{array}{l}0.550 \\
* *\end{array}$ \\
\hline & $\begin{array}{l}(0.737 \\
)\end{array}$ & $\begin{array}{l}(0.3 \\
22)\end{array}$ & $(0.237)$ & $(0.275)$ & $\begin{array}{l}(0.43 \\
0)\end{array}$ & $(0.339)$ & $(0.523)$ & $(0.344)$ & $(0.243)$ & $(0.189)$ & $\begin{array}{l}(0.19 \\
9)\end{array}$ \\
\hline \multirow[t]{2}{*}{$\begin{array}{l}\text { OPE } \\
\text { N_S } \\
\text { W } \\
\end{array}$} & $\begin{array}{l}0.335 * \\
* *\end{array}$ & \begin{tabular}{|l}
0.3 \\
$60 *$ \\
$* *$ \\
\end{tabular} & $\begin{array}{l}0.268 * * \\
*\end{array}$ & $\begin{array}{l}0.324 * * \\
*\end{array}$ & $\begin{array}{l}0.296 \\
* * *\end{array}$ & $\begin{array}{l}0.313 * \\
* *\end{array}$ & $\begin{array}{l}0.319 * * \\
*\end{array}$ & $\begin{array}{l}0.320 * * \\
*\end{array}$ & $\begin{array}{l}0.318 * * \\
*\end{array}$ & $\begin{array}{l}0.332 * * \\
*\end{array}$ & $\begin{array}{l}0.304 \\
* * *\end{array}$ \\
\hline & $\begin{array}{l}(0.065 \\
5)\end{array}$ & $\begin{array}{l}(0.0 \\
613 \\
)\end{array}$ & $\begin{array}{l}(0.0654 \\
)\end{array}$ & $(0.0656)$ & $\begin{array}{l}(0.06 \\
46)\end{array}$ & $\begin{array}{l}(0.065 \\
0)\end{array}$ & $(0.0654)$ & $(0.0646)$ & $\begin{array}{l}(0.0649 \\
)\end{array}$ & $(0.0646)$ & $\begin{array}{l}(0.06 \\
62)\end{array}$ \\
\hline $\begin{array}{l}\text { EXD } \\
\text { BST } \\
\text { OC }\end{array}$ & \begin{tabular}{|l}
- \\
0.0064 \\
$1 * * *$
\end{tabular} & $\begin{array}{l}- \\
0.0 \\
069 \\
2 * * \\
*\end{array}$ & $\begin{array}{l}- \\
0.00857 \\
* * *\end{array}$ & $\begin{array}{l}- \\
0.00691 \\
* * *\end{array}$ & $\begin{array}{l}- \\
0.007 \\
63 * * \\
*\end{array}$ & $\begin{array}{l}- \\
0.0072 \\
8 * * *\end{array}$ & $\begin{array}{l}- \\
0.00700 \\
* * *\end{array}$ & $\begin{array}{l}- \\
0.00618 \\
* * *\end{array}$ & $\begin{array}{l}- \\
0.00724 \\
* * *\end{array}$ & $\begin{array}{l}- \\
0.00745 \\
* * *\end{array}$ & $\begin{array}{l}- \\
0.007 \\
57 * * *\end{array}$ \\
\hline
\end{tabular}




\begin{tabular}{|c|c|c|c|c|c|c|c|c|c|c|c|}
\hline & $\begin{array}{l}(0.001 \\
04)\end{array}$ & $\begin{array}{l}(0.0 \\
009 \\
20) \\
\end{array}$ & $\begin{array}{l}(0.0010 \\
2)\end{array}$ & $\begin{array}{l}(0.0010 \\
1)\end{array}$ & $\begin{array}{l}(0.00 \\
0958)\end{array}$ & $\begin{array}{l}(0.000 \\
973)\end{array}$ & $\begin{array}{l}(0.0010 \\
2)\end{array}$ & $\begin{array}{l}(0.00110 \\
)\end{array}$ & $\begin{array}{l}(0.0009 \\
56)\end{array}$ & $\begin{array}{l}(0.00095 \\
1)\end{array}$ & $\begin{array}{l}(0.00 \\
104)\end{array}$ \\
\hline \multirow{2}{*}{$\begin{array}{l}\text { REA } \\
\text { L_IN } \\
\text { TER } \\
\text { EST } \\
\end{array}$} & $\begin{array}{l}- \\
0.0625 \\
* *\end{array}$ & $\begin{array}{l}- \\
0.0 \\
324\end{array}$ & $\begin{array}{l}- \\
0.0493 * \\
*\end{array}$ & $\begin{array}{l}- \\
0.0641 * \\
*\end{array}$ & \begin{tabular}{|l|}
- \\
0.059 \\
$8 * *$
\end{tabular} & $\begin{array}{l}- \\
0.0603 \\
* *\end{array}$ & $\begin{array}{l}- \\
0.0598 * \\
*\end{array}$ & $\begin{array}{l}- \\
0.0557 * \\
*\end{array}$ & $\begin{array}{l}- \\
0.0589 * \\
*\end{array}$ & $\begin{array}{l}- \\
0.0569 * \\
*\end{array}$ & $\begin{array}{l}- \\
0.057 \\
8 * *\end{array}$ \\
\hline & $\begin{array}{l}(0.024 \\
5)\end{array}$ & $\begin{array}{l}(0.0 \\
233 \\
) \\
\end{array}$ & $\begin{array}{l}(0.0245 \\
)\end{array}$ & $(0.0248)$ & $\begin{array}{l}(0.02 \\
43)\end{array}$ & $\begin{array}{l}(0.024 \\
6)\end{array}$ & $(0.0246)$ & $(0.0246)$ & $\begin{array}{l}(0.0246 \\
)\end{array}$ & $(0.0244)$ & $\begin{array}{l}(0.02 \\
48)\end{array}$ \\
\hline \multirow[t]{2}{*}{$\begin{array}{l}\text { DEV } \\
\text { _FIN }\end{array}$} & $\begin{array}{l}0.261 * \\
* *\end{array}$ & $\begin{array}{l}0.2 \\
16 * \\
* *\end{array}$ & $\begin{array}{l}0.257 * * \\
*\end{array}$ & $\begin{array}{l}0.261 * * \\
*\end{array}$ & $\begin{array}{l}0.253 \\
* * *\end{array}$ & $\begin{array}{l}0.260 * \\
* *\end{array}$ & $\begin{array}{l}0.267 * * \\
*\end{array}$ & $\begin{array}{l}0.266^{* *} \\
*\end{array}$ & $\begin{array}{l}0.264 * * \\
*\end{array}$ & $\begin{array}{l}0.252 * * \\
*\end{array}$ & $\begin{array}{l}0.261 \\
* * *\end{array}$ \\
\hline & $\begin{array}{l}(0.042 \\
7)\end{array}$ & $\begin{array}{l}(0.0 \\
445 \\
)\end{array}$ & $\begin{array}{l}(0.0423 \\
)\end{array}$ & $(0.0429)$ & $\begin{array}{l}(0.04 \\
26)\end{array}$ & $\begin{array}{l}(0.044 \\
1)\end{array}$ & $(0.0438)$ & $(0.0428)$ & $\begin{array}{l}(0.0429 \\
)\end{array}$ & $(0.0427)$ & $\begin{array}{l}(0.04 \\
29)\end{array}$ \\
\hline \multirow[t]{2}{*}{$\begin{array}{l}\text { SCH } \\
\text { OOL } \\
\text { SEC }\end{array}$} & $\begin{array}{l}0.135^{*} \\
* *\end{array}$ & $\begin{array}{l}0.1 \\
32 * \\
* *\end{array}$ & $\begin{array}{l}0.150 * * \\
*\end{array}$ & $\begin{array}{l}0.137 * * \\
*\end{array}$ & $\begin{array}{l}0.126 \\
* * *\end{array}$ & $\begin{array}{l}0.140 * \\
* *\end{array}$ & $\begin{array}{l}0.141 * * \\
*\end{array}$ & $\begin{array}{l}0.137 * * \\
*\end{array}$ & $\begin{array}{l}0.139 * * \\
*\end{array}$ & $\begin{array}{l}0.135^{* *} \\
*\end{array}$ & $\begin{array}{l}0.141 \\
* * *\end{array}$ \\
\hline & $\begin{array}{l}(0.031 \\
1)\end{array}$ & $\begin{array}{l}(0.0 \\
296 \\
)\end{array}$ & $\begin{array}{l}(0.0309 \\
)\end{array}$ & $(0.0313)$ & $\begin{array}{l}(0.03 \\
13)\end{array}$ & $\begin{array}{l}(0.031 \\
2)\end{array}$ & $(0.0312)$ & $(0.0311)$ & $\begin{array}{l}(0.0312 \\
)\end{array}$ & $(0.0309)$ & $\begin{array}{l}(0.03 \\
12)\end{array}$ \\
\hline \multirow[t]{2}{*}{$\begin{array}{l}\text { Const } \\
\text { ant }\end{array}$} & $\begin{array}{l}15.43 * \\
* *\end{array}$ & $\begin{array}{l}11 . \\
20 * \\
* *\end{array}$ & $\begin{array}{l}22.84 * * \\
*\end{array}$ & $\begin{array}{l}12.80 * * \\
*\end{array}$ & $\begin{array}{l}12.73 \\
* * *\end{array}$ & $\begin{array}{l}16.02 * \\
* *\end{array}$ & $\begin{array}{l}14.31 * * \\
*\end{array}$ & $\begin{array}{l}12.95 * * \\
*\end{array}$ & $\begin{array}{l}14.72 * * \\
*\end{array}$ & $\begin{array}{l}20.62 * * \\
*\end{array}$ & $\begin{array}{l}16.78 \\
* * *\end{array}$ \\
\hline & $\begin{array}{l}(1.353 \\
)\end{array}$ & $\begin{array}{l}(1.5 \\
91) \\
\end{array}$ & $(2.539)$ & $(3.092)$ & $\begin{array}{l}(1.71 \\
7) \\
\end{array}$ & $(3.094)$ & $(2.373)$ & $(1.911)$ & $(1.577)$ & $(2.254)$ & $\begin{array}{l}(2.01 \\
2)\end{array}$ \\
\hline $\begin{array}{l}\text { Obse } \\
\text { rvati } \\
\text { ons } \\
\end{array}$ & 399 & 365 & 399 & 399 & 399 & 399 & 399 & 399 & 399 & 399 & 399 \\
\hline $\begin{array}{l}\text { Num } \\
\text { ber of } \\
\text { ID }\end{array}$ & 21 & 21 & 21 & 21 & 21 & 21 & 21 & 21 & 21 & 21 & 21 \\
\hline $\begin{array}{l}\text { R- } \\
\text { squar } \\
\text { ed }\end{array}$ & 0.791 & $\begin{array}{l}0.7 \\
07\end{array}$ & 0.704 & 0.786 & 0.798 & 0.784 & 0.784 & 0.791 & 0.786 & 0.798 & 0.785 \\
\hline
\end{tabular}

\section{Source: Author from secondary databases}

The observation of these tables suggests the following analyzes:

- ICRG investment climate variables are more significant in the private investment model; which is a sign that they are having an impact more indirectly than directly on economic growth;

- The composite investment climate variable (CL_INVEST_ICRG) has the greatest impact in economic growth and private investment models (columns 1 in tables $\overline{6}$ and 7 ). In this case, an improvement 
in the quality of the investment climate by one unit, leads, all other things being equal, to an increase in the economic growth rate of $1.165 \%$ and an increase in private investment by $1.460 \%$;

- The variables ethnic tensions (ETHNI_TENSION_ICRG) and external conflicts (EXTERN_CONFL_ICRG) have a significant direct impact (at 5\%) $(0.35 \%$ and $0.464 \%$ respectively) on economic growth (columns 6 and 3 of table 6);

- Just as in the KKM database, the fight against corruption (CORRUPT_ICRG) and the promotion of democracy (DEMO_ACCOUNT_ICRG) of the ICRG base, have a significant direct and indirect impact on economic growth (respectively columns 4 and 7 of table 6 and columns 5 and 8 of table 7). In this case, it appears that a reduction in the risk of corruption of a unit, leads, all other things being equal, to an increase in the economic growth rate by $0.453 \%$ and the private investment rate by $1.174 \%$. With regard to the ethnic tensions variable, a reduction in the risk of one unit translates all other things being equal, by an increase in the economic growth rate of $0.35 \%$;

- Although the impact of the protection of private property rights (RIGHTS_FI) is significant in several equations of the economic growth model, the influence of this variable seems undoubtedly to be exerted through the channel of private investment. This result is the same regardless of the database considered. The same is true of trade openness and financial development, the average effects on private investment of $0.318 \%$ ( $0.327 \%$ under the KKM base) and $0.257 \%$ ( $0.252 \%$ in KKM), respectively;

- The result obtained for the human capital variable is similar to that obtained within the framework of the KKM base. In this case, there is a significant (1\%) and positive average impact estimated at $0.137 \%$ $(0.129 \%$ within the framework of the KKM base); which indicates the importance of the quality of human capital for investors.

\section{Conclusion}

The purpose of this article was to examine the impact of the investment climate on economic growth. To do this, from a sample of 21 countries in sub-Saharan Africa over the period 1996-2014, we used two main databases of the components of the investment climate: the Kaufmann, Kraay and Mastruzzi database (2015) and that of the International Country Risk Guide. From these, two composite investment climate variables were constructed using the PCA method. Based on the work of Poirson (1998) and Nawaz et al. (2014), a panel data modeling was used following a two-step approach: first, we assessed the direct impact of individual and composite variables of the investment climate on economic growth for each of the databases; then, it was a question of capturing the indirect impact of these institutional variables, through the channel of private investment. It appears in substance from the analysis carried out the following:

- The investment climate taken as a whole, is a real engine of economic growth. Indeed, the results obtained from the two databases show a very significant and positive impact of this variable on economic growth, whether directly or indirectly through the channel of private investment. We find, despite different configurations of what is called here investment climate, similar results in the work of Valeriani et al. (2011) and Brunetti (1997);

- The specific components of the investment climate, which can easily guide the recommendations for action by public authorities, are just as significant with direct and indirect positive impacts on economic growth. The fight against corruption, the protection of private property rights, the efficiency of government, the quality of bureaucracy and regulation are among the most decisive;

- trade openness and financial development, which are components of what Aysan et al. (2005) call for structural reforms, have significant and positive impacts on private investment; thus, acting indirectly on economic growth. The lack of relevant structural reforms being one of the major constraints facing SSA countries, the public authorities should pay particular attention to it because they constitute an important determinant of the present and future profitability of private investment. Indeed, a developed financial system mobilizes and allocates resources to companies just as, due to a higher specialization in technologies, it leads to a better selection of projects and to a greater diversification of risks, with as results increase in investment projects financed by companies and an increase in the productivity of new investments (Levine, 1997). Similarly, trade openness increases competitiveness and provides access to larger markets (Balassa, 1978; Feder, 1982). Thus, it can be at the origin of economies of scale and competitiveness gains;

- Human capital (whose proxy in this article is the secondary school enrollment rate) has a positive indirect impact on economic growth through private investment. Indeed, human capital stimulates the 
formation of private capital by increasing the profitability of investment. Likewise, the quality of human capital is a guarantee of productivity for companies, since skilled workers are better able to adapt to changes, in this case the adoption of new, more productive technologies.

Overall, it is safe to say that investor perception of government effectiveness is a major determinant of economic growth. This efficiency is translated at the operational level by the quality of the regulations, a judicial system capable of ensuring better protection of private property rights and guaranteeing the enforceability of contracts, social justice and equity, promotion democracy through the transparency and reliability of the mechanisms for expressing the political choices of citizens, freedom of expression, association and the media; all of which contribute to the preservation of political stability as well as to the prevention of corruption which is therefore only the symptom of a deeper evil. The public authorities of SSA countries must take sufficient advantage of these levers of the investment climate which, beyond being determinants of economic growth, are the bases of a modern transformation of the structure of these economies; sine qua non condition for the much sought-after development of Africa.

\section{Appendices}

Annex 1: List of countries in the study sample

\begin{tabular}{|l|l|l|}
\hline $\mathbf{N}^{\circ}$ & Pays $\quad$ South Africa & Code \\
\hline 1 & \multicolumn{1}{|c|}{ ZAF } \\
\hline 2 & Angola & AGO \\
\hline 4 & Botswana & BWA \\
\hline 5 & Burkina Faso & BFA \\
\hline 6 & Cameroon & CMR \\
\hline 7 & Congo & COG \\
\hline 8 & Democratic Republic of Congo & ZAR \\
\hline 9 & Ivory Coast & CIV \\
\hline 10 & Gabon & GAB \\
\hline 11 & Ghana & GHA \\
\hline 12 & Guinea & GIN \\
\hline 13 & Liberia & LBR \\
\hline 14 & Mali & MLI \\
\hline 15 & Mozambique & MOZ \\
\hline 16 & Niger & NAM \\
\hline 17 & Uganda & NER \\
\hline 18 & Senegal & UGA \\
\hline 19 & Sierra Leone & SEN \\
\hline 20 & Tanzania & TGO \\
\hline 21 & Togo & SLE \\
\hline
\end{tabular}




\section{Source: Author}

Annex 2: Correlations between KKM variables and factors

\begin{tabular}{|l|l|l|}
\hline & \multicolumn{1}{|c|}{ F1 } & \multicolumn{1}{|c|}{ 2 } \\
\hline VOICE_ACCOUNT_KKM & $\mathbf{0 , 9 5 6}$ & $-0,248$ \\
\hline POL_STABIL_ABS_VIOLENCE_KKM & $\mathbf{0 , 8 6 5}$ & 0,140 \\
\hline GOV_EFFECTIV_KKM & $\mathbf{0 , 9 6 9}$ & $-0,039$ \\
\hline REGUL_QUAL_KKM & $\mathbf{0 , 9 7 1}$ & 0,081 \\
\hline RUL_LAW_KKM & $\mathbf{0 , 9 7 1}$ & $-0,071$ \\
\hline CONTROL_CORRUPT_KKM & $\mathbf{0 , 9 5 8}$ & $-0,044$ \\
\hline RIGHTS_FI & $\mathbf{0 , 9 2 0}$ & 0,150 \\
\hline
\end{tabular}

\section{Source: Author}

Annex 3: Distribution of factor axes according to ICRG criteria

\begin{tabular}{|l|l|l|l|l|}
\hline & F1 & F2 & F3 & F4 \\
\hline Valeur propre & 8,329 & 1,450 & 1,330 & 0,735 \\
\hline Variabilité (\%) & 59,496 & 10,360 & 9,497 & 5,253 \\
\hline$\%$ cumulé & 59,496 & 69,856 & 79,353 & 84,606 \\
\hline
\end{tabular}

Source:Author from the CPA.

Annex 4: Correlations between ICRG variables and axis

\begin{tabular}{|l|l|l|l|}
\hline \multirow{2}{*}{ Variables } & \multicolumn{2}{l}{ Axes } & F3 \\
\cline { 2 - 4 } & F1 & F2 & 0,157 \\
\hline GOVT_STABILITY_ICRG & 0,420 & $\mathbf{0 , 7 7 9}$ & 0,021 \\
\hline INTERN_CONFL_ICRG & $\mathbf{0 , 8 4 1}$ & 0,341 & $-0,086$ \\
\hline EXTERN_CONFL_ICRG & $\mathbf{0 , 6 7 6}$ & 0,665 & 0,145 \\
\hline CORRUPT_ICRG & $\mathbf{0 , 6 7 0}$ & $-0,237$ & 0,457 \\
\hline LAW_ORDER_ICRG & $\mathbf{0 , 6 6 9}$ & $-0,251$ & 0,345 \\
\hline ETHNI_TENSION_ICR & $\mathbf{0 , 8 1 7}$ & 0,085 & $-0,212$ \\
\hline DEMO_ACCOUNT_ICRG & $\mathbf{0 , 8 1 2}$ & 0,410 & $-0,248$ \\
\hline BUREAU_QUAL_ICRG & $\mathbf{0 , 6 5 5}$ & $-0,356$ & 0,026 \\
\hline INVEST_PROFIL_ICRG & $\mathbf{0 , 8 8 6}$ & $-0,041$ & $-0,032$ \\
\hline RIGHTS_FI & $\mathbf{0 , 9 4 4}$ & $-0,108$ & $-6,149$ \\
\hline Condi_socio_eco & 0,426 & $-0,266$ & $-0,894$ \\
\hline Miltair_politic & 0,046 & 0,031 & \\
\hline
\end{tabular}

Source: Author

6. References

${ }^{8}$ Values in bold are those greater than 0.6.

N. Pagbe Rémi Degourmond, IJSRM Volume 08 Issue 04 April 2020 [www.ijsrm.in] 
[1.] North, D. C. (1990). Institutions, Institutional Change and Economic Performance. Economic Development and Cultural Change, vol. 41, No. 2; pp. 419-422.

[2.] La Porta R.; Lopez-de-Silanes F.; Shleifer A. and Vishny R. (1997). "Legal Determinants of External Finance", Journal of Finance, Vol.52, N³, pp.1131-1150.

[3.] La Porta, R. ; Lopez de Silanes, F. ; Shleifer, A. ; and Vishny, R. W. (1999). The quality of government. Journal of Law, Economics, and Organization, 15(1), 222-279.

[4.] Acemoglu, D.; Johnson, S. and Robinson, J. (2005). The rise of Europe: Atlantic trade, institutional change, and economic growth. American Economic Review, 95(3), pp. 546-579.

[5.] Acemoglu, D.; Johnson, S.; and Robinson, J. (2005). "Institutions as a Fundamental Cause of Long-Run Growth". In Handbook of Economic Growth, Vol. 1, Part A. North Holland: Elsevier.

[6.] CNUCED (2012). Le Développement Economique en Afrique : Catalyser l'investissement pour une croissance transformatrice en Afrique. Publication des Nations-Unies. No. E.12.11. D.10. New York et Genève.

[7.] Acemoglu, Daron; Naidu, Suresh; Restrepo, Pascal and Robinson, James A. (2014). Democracy does cause growth; Working paper 20004; National Bureau of Economic Research, 1050; Massachusetts Avenue Cambridge, MA 021.

[8.] Clarke, D. (2013). Africa 2050: Economic revolution. Global: The International Briefng. Second quarter, pp. 18-19. Available at http://www.global-briefng.org/Global_ Issue_14/index.html\#/20/ (accessed 23 March 2014).

[9.] Grindle, Merilee (2004) "Good enough governance: Poverty reduction and reform in developing countries". Governance: An international journal of policy, administration and institutions 17 (4): 525-548.

[10.] Rothstein, Bo and Uslaner, Eric M. (2005). All for All: Equality and Social Trust. LSE Health and Social Care Discussion Paper No. 15. Available at SSRN: https://ssrn.com/abstract=824506 or http://dx.doi.org/10.2139/ssrn.824506.

[11.] Hasan, R., Mitra, D., and Ulubasoglu, M. (2007). Institutions and policies for growth and poverty reduction: The role of private sector development. Asian Development Review, 24, 69116.

[12.] Banque Mondiale (2005). Rapport sur le développement dans le monde : Un Meilleur climat de l'investissement pour tous. Washington, Banque Mondale.

[13.] Valeriani, Elisa and Peluso, Sara (2011). The impact of institutional quality on economic growth and development: an empirical study. Journal of Knowledge Management, Economics and Information Technology.

[14.] Rodrik, Dani; Subramanian, Arvind and Trebbi, Francesco (2004). "Institutions rule: The primacy of institutions over geography and integration in economic development"; Journal of Economic Growth, vol. 9, Issue 2, pp. 131-165.

[15.] Hall, R. and Jones, C. I. (1999). Why do some countries produce so much more output per worker than others? The Quarterly Journal of Economics 114(1, February):83-116.

[16.] Kaufmann, D.; Kraay, A. and Zoido-Lobatón, P. (1999b). “Governance matters.” World Bank Policy Research Working Paper 2196, Washington DC.

[17.] Knack, S. and Keefer, P., (1995). Institutions and economic performance: cross-country tests using alternative institutional measures. Economics and Politics 7, 207-227.

[18.] Brunetti, Aymo; Kisunko, Gregory and Weder, Beatrice (1997). Credibility of rules and economic growth: evidence from a worldwide survey of the private sector. The World Bank Economic Review, vol. 12. No.3: 353-84.

[19.] Zouhaier, Hadhek (2012). Institutions, Investment and Economic Growth. International Journal of Economics and Finance, vol. 4; No.2. www.ccsenet.org/ijef. Doi :10.5539/ijef. v4n2p152.

[20.] Straub, T.; Grimaud, C.; Gilfillan, G.D.; Mitterweger, A. and Becker, P.B. (2008). The chromosomal high-affinity binding sites for the Drosophila dosage compensation complex. PLoS Genet. 4(12): e1000302. studies, 46(6): 1047-1066.

[21.] Jerzmanowski, Michal (2006). Empirics of hills, plateaus, mountains and plains: a markovswitching approach to growth. Journal of Development Economics, vol. 81, issue 2; pp. 357-385. 
[22.] Guetat, Imène (2006). The effects of corruption on growth performance of the MENA countries. Journal of Economics and Finances; vol.30, issue 2; pp. 208-221.

[23.] Johnson, Simon; McMillan, John and Woodruff, Christopher (2002). "Property rights and finance"; American Economic Review, vol. 92, No. 5, pp. 1335-1356.

[24.] Kaufmann, D. and Kraay, A. (2002) “Growth Without Governance.” Economia 3 (1): 169-215.

[25.] Ehrilich, I. and Francis T. L. (1999). Bureaucratic Corruption and Endogenous Economic Growth, Journal of Political Economy, 107, 270-293.

[26.] Poirson, Helen (1998). Economic security, private investment and growth in developing countries. IMF working paper No.WP/98/4.

[27.] La Porta R.; Lopez-de-Silanes F.; Shleifer A. and Vishny R. (1997). "Legal Determinants of External Finance", Journal of Finance, Vol.52, N’3, pp.1131-1150.

[28.] Knack, S. and Keefer, P. (1997a). "Why don't poor countries catch up? A cross-national test of an institutional explanation. " Economic Inquiry, 35, 590-602.

[29.] Alesina, A., and Perotti, R. (1996). "Income Distribution, Political Instability, and Investment."

[30.] Mauro, P. (1995). “Corruption and growth". Quarterly Journal of Economics, 110: 681-712.

[31.] Gyimah-Brempong, K. and De Camacho, S. M. (2006). Corruption, growth, and income distribution: Are there regional differences? Economics of Governance, 7, 245-269.

[32.] Barro R. J. and Sala-i-Martin, X. (1995). Economic Growth, McGraw-Hill.

[33.] Hadjimichael, Michael and Ghura, Dhaneshwar (1995). "Growth in Sub-saharan Africa"; IMF Working paper, vol. 95, pp. 1-32.

[34.] Fosu, A.K. (1992). Political Instability and Economic Growth: Evidence from Sub-Saharan Africa. Economic Development and Cultural change, 40 (4), 829-841. http://dx.doi.org/10.1086/451979.

[35.] Scully, G.W. (1992). Constitutional Environments and Economic Growth, Princeton University Press, Princeton.

[36.] Loayza, Norma; Easterly, William and Montiel, Peter (1997). "Has Latin America's postreform growth been disappointing?"; Journal of International Economics, Elsevier, vol. 43(3-4); pp. 287-311.

[37.] Demetriades, Panicos and Hussein, Khaled A. (1996). Does financial development cause economic growth? Times-series evidence from 16 countries. Journal of Development Economics, vol. 51, issue 2, 387-411.

[38.] Squalli J. and Wilson K. (2011). “A New Measure of Trade Openness”, World Economy, 34, p. 1745-1770. 